\title{
Stock Mergers and Acquirers' Subsequent Stock Price Crash Risk
}

\begin{abstract}
We examine the changes in acquirers' stock price crash risk following mergers and acquisitions (M\&As). We employ the three measures of crash risk most commonly used in the literature: the negative conditional skewness of acquirer-specific stock returns, a down-toup volatility measure, and the excess of extreme negative stock returns over extreme positive returns. We find that stock acquirers experience significantly higher stock price crash risk as compared to cash acquirers. The change in risk is positively correlated with the percent of stock used as a payment method. The findings are confined to acquirers with overvalued stock, lower profitability and more financial constraints, as well as to acquisitions of public targets. We confirm that the financial crisis 2007-2009 period does not drive our findings. Furthermore, our results are robust to endogeneity concerns, controlling for non-acquirers and post-merger acquirer changes.
\end{abstract}

JEL classification: G14; G34

Keywords: Mergers and Acquisitions; Crash Risk; Stock Price Crash Risk 


\section{Stock Mergers and Acquirers' Subsequent Stock Price Crash Risk}

\section{Introduction}

A large number of studies document poor long-run stock price performance by stockfinanced acquiring firms (Loughran and Vijh (1997), Rau and Vermaelen (1998), and Betton, Eckbo, and Thorburn (2008)). This study examines the change in acquirers' stock price crash risk following M\&As. While prior studies focus on return (first moment) and risk (second moment) of the acquiring firms, we focus on the third moment of the stock return distribution, an important factor that is priced by investors (Harvey and Siddique, 2000).

The method of payment remains central to M\&A studies since a stock-financed bid provides different signals about the acquiring firm's valuation than a cash-financed bid (also see, Oler and Waegelein (2011); and, Bowers, Moore and Tse (2000)) ${ }^{1}$. Brown and Ryngaert (1991) present evidence that tax considerations will lead bidders with unfavorable private information to offer stock as payment. Martin (1996) shows that firms that use stock in acquisitions have lower book-to-market ratios (which would be associated with overvalued firms) than firms that use cash. Shleifer and Vishny (2003) present an M\&A model based on the misvaluations of bidder and target firms. Their model suggests that overvalued firms are more likely to become acquirers, and undervalued firms are more likely to become takeover $\operatorname{targets}^{2}$. Rhodes-Kropf and Viswanathan (2004) show that when markets are overvalued, mergers are more likely to occur and those that occur are more likely to be financed by stock. Rhodes-Kropf, Robinson and Viswanathan (2005), Ang and Cheng (2006) and Dong, Hirshleifer, Richardson, and Teoh (2006) find that merger waves are more likely in the presence of high market-to-book (M/B) ratios. Chidambaran, John, Shangguan and

\footnotetext{
${ }^{1}$ See also Shih and Hsu (2009) for how different combinations of payment methods and acquirer valuation suggest different motives behind acquisitions

2 Jovanovic and Rousseau (2002) posit a slightly different motivation through the reallocation of capital.
} 
Vasudevan (2010) find that bidders are more likely to use stock financing following stock price run-ups and in hot merger markets. In particular, Alexandridis et al. (2012) compare the mid-2000s merger wave to the earlier 1990s merger wave and find both less acquirer overvaluation (relative to targets) and more pronounced use of cash as payment. Dong, Hirshleifer, Richardson, and Teoh (2006) and Ang and Chen (2006) also find that overvalued acquirers are associated with higher M\&A premia. Erel et al. (2012) report that acquirers in cross-border M\&As tend to come from countries with rising stock markets and high marketto-book ratios. These findings point to the usage of overvalued securities in stock-financed takeovers.

Investors, though, slowly correct the overvaluation of the merged firms' shares postM\&A (Shleifer and Vishny, 2003; Baker, Ruback, and Wurgler, 2007). This helps explain the negative drift in acquirers' long-term abnormal returns, as documented by Loughran and Vijh (1997), Rau and Vermaelen (1998), Mitchell and Stafford (2000), Moeller, Schlingemann, and Stulz (2005), and Savor and Lu (2009). Furthermore, Langetieg, Haugen, and Wichern (1980) examine a sample of mergers involving the exchange of only common stock (sample size of 82) and find an increase in bidders' stock systematic, total and diversifiable risks from before to after the merger.

In this paper, we examine the relation between the payment method in M\&As and the subsequent change in firm-specific stock price crash risk. Following Chen, Hong and Stein (2001), Kim, Li and Li (2014), and An, Wu and Wu (2016), we define crash risk as the conditional skewness of a return distribution, which is its third moment. It captures asymmetry in risk, especially downside risk. It is well documented that the distribution of stock returns is characterized by negative skewness, i.e., large negative stock returns and stock price crashes dominate large positive stock price returns. 
The possible sources of negative skewness following M\&A are multiple. First, it could be due to bidder firm managerial hubris leading them to unintentionally overestimate gains from M\&A. Second, it could be due to agency conflicts. Parvinen and Tikkanen (2007) examine the sources of incentive asymmetries in M\&As. They include the motivations of empire-building managers, dealmakers, investment bankers and M\&A consultants, which often lead to the selection of targets that maximize these parties' interests (for instance, managers' compensation) as opposed to shareholders' interests (also see Allen, Jagtiani, Peristiani and Saunders, 2004) ${ }^{3}$. Such agency conflicts often lead managers and their advisers to intentionally overestimate the strategic fit and the gains from their preferred M\&A targets. Subsequently, the failure of the expected synergies to materialize increases the bidder's stock price crash risk.

Third, to minimize losses associated with unsuccessful M\&As, it would be more prudent for an acquirer to fund the M\&A deal using stock. Should the deal turn out to be less than successful, the potential losses are shared by both acquirer and target shareholders. As such, a stock acquisition might convey a negative signal about the acquisition's prospects. There exists ample evidence that investors interpret a stock issuance as a sign that the company's managers believe the stock to be overvalued (see Spiess and Affleck-Graves, 1995). This overvaluation is corrected over time through a downward adjustment in the stock price. We therefore hypothesize that a stock bid signals to investors that the acquirer's shares are overvalued and that its management does not share the same level of confidence in the acquisition as in a cash offer. In the long run, following the M\&A, these signals add to the bidder's large negative stock returns and stock price crashes.

\footnotetext{
${ }^{3}$ In the context of incentives that go beyond shareholder wealth maximization, Lee and Wang (2017) find that having politically connected directors increases crash risk.
} 
To test our conjecture of the relation between stock mergers and stock price crash risk, we examine the change in bidders' stock price crash risk from the year before to the year following the M\&A. We measure firm-specific crash risk by (i) the negative skewness of firm-specific weekly returns, (ii) the asymmetric volatility of negative and positive stock returns, and (iii) the excess of the number of large negative stock returns over the number of large positive stock returns. Using a sample of 6,926 U.S. completed domestic M\&As from 1985 to 2015, we find a significantly positive association between stock-financed M\&As and changes in all three measures of stock price crash risk. The results are robust after controlling for other factors contributing to stock price crash risk. Similarly, we observe that post-M\&A stock price crash risk is positively associated with the percentage of stock used in the overall acquisition payment mix. As further evidence of stock acquisitions signaling bidder overvaluation, the significantly higher post-M\&A stock price crash associated with stock acquisitions is confined to the subsample of acquirers with higher than the median industry market-to-book ratio (a proxy for overvaluation). In sum, and consistent with the literature documenting reduced shareholder wealth in stock-financed acquisitions, the new findings documented in this paper suggest that stock-financed M\&As undermine shareholder interest.

To mitigate endogeneity concerns, we use the Heckman two-stage self-selection model. In addition, we test whether the positive association between stock mergers and increases in bidders' stock price crash risk is moderated by the target public status, acquirer's profitability, acquirer's leverage, and whether the M\&A occurred during a period of financial crisis. We find the effect to be more significant amongst public targets, less profitable and highly leveraged bidders, and during the non-crisis periods. We also confirm that it is the acquisition act rather than mere overvaluation that is driving our results by comparing acquirers to non-acquirers based on industry and size. The findings persist after we control for post-merger changes to the acquiring firm. 
Our findings add to the literature on the financial risk consequences of M\&As. There is a preponderance of papers on the impact of M\&As on firm performance, more specifically stock return; however, the literature on firm risk is still emergent. Instead of focusing on return (first moment) and risk (second moment), we focus on the M\&A effects on crash risk, which is the third moment of the stock return distribution and is an important characteristic that is priced by investors (Harvey and Siddique, 2000; and, Tee, Yee and Chong, 2018). The results thus broaden our understanding of the effects of M\&As on acquiring firms and their investors.

The rest of the paper proceeds as follows. We review the literature and formulate our hypotheses in Section II. The sample and methods used are explained in Section III. Results are presented and explained in Section IV. The final section concludes the paper.

\section{Literature Review and Hypotheses Development}

\section{Stock-For-Stock Mergers}

Agency theory has long posited that dubious motivation of acquiring managers may lead to wealth-destroying acquisitions (Mueller (1972) and Jensen (1986, 1993)). Conversely, the neoclassical theory (Maksimovic and Phillips (2013), and Arikan and Stulz (2015)) depicts M\&A as a response to industry shocks by wealth maximizing firms (also see Servaes, 1991). These theories though do not explain bidders' choice of the method of payment in M\&As.

The misvaluation theory — or overvaluation hypothesis — (Shleifer and Vishny (2003) and Rhodes-Kropf and Viswanathan (2004)) suggests that firms' decision to engage in M\&A is in large part related to their stock misvaluation. Likewise, the stock market driven acquisition theory of Shleifer and Vishny (2003) proposes that rational managers use stock- 
for-stock mergers to profit from stock market inefficiency. Consequently, managers are inclined to use stock (cash) to finance acquisitions when their shares are overpriced (underpriced). To the degree that overvaluations are not supported indefinitely, a correction in bidders' stock valuations post-M\&A is to be expected (Fu, Lin, and Officer, 2013), which would contribute to their stock price crash risk following stock-for-stock mergers.

Ben-David, Drake, and Roulstone (2015) findings indirectly support acquirers'stock price crash risk. Specifically, the authors find short interest to be substantially higher for stock acquirers than for cash acquirers. The authors also document an inverse association between acquirers' long-run stock returns and the level of short interest in their stocks immediately prior to the acquisition. The findings of other studies also support a fall in acquirers' share price post-M\&A (Loughran and Vijh (1997) and Rau and Vermaelen (1998)). To the extent that overvalued equity leads managers to engage in stock-for-stock mergers, it follows that their post-merger stock price crash risk should be higher relative to cash-for-stock mergers.

H1: $\quad$ Stock acquirers are positively associated with stock price crash risk

\section{Overvalued Acquirers}

Fu, Lin, and Officer (2013) show that overvalued acquirers significantly overpay for their targets. Such acquisitions fail to deliver synergy gains and are concentrated among acquirers with governance problems; acquirer could be looking to cash in its overvalued shares at the expense of due diligence (see: AOL - Time Warner ${ }^{4}$ ). They also identify stock-

\footnotetext{
${ }^{4}$ See, for example, http://archive.fortune.com/magazines/fortune/fortune archive/2002/02/04/317481/index.htm, or any other AOL - Time Warner story recap
} 
swap mergers for which the acquirer has the largest relative stock price overvaluation compared to the target prior to the acquisition announcement and find that the acquirer's overvaluation relative to the target quickly dissipates (driven by a decrease in the acquirer's stock price) once the deal is announced.

Several papers examine the fall in the stock price of overvalued acquiring firms. For instance, Akbulut (2013) finds that overvalued equity drives managers to make stock acquisitions, which destroy value for their shareholders as evidenced by the negative stock returns post-acquisition. Song (2007) documents a strong relation between pre-M\&A insider trading patterns and post-M\&A long-run performance and suggests that overvalued acquirers perform value-destroying acquisitions.

Using the market-to-book ratio as a direct proxy for acquirer's pre-M\&A overvaluation (Moeller, Schlingemann, and Stulz (2005)), we divide our sample into two. We categorize acquirers with an industry-adjusted positive market-to-book ratio at the end of the fiscal year preceding the deal announcement as overvalued acquirers. Those with a negative ratio are categorized as undervalued acquirers. We hypothesize that it is in the group of overvalued acquirers that stock acquisitions would be associated with a higher likelihood of experiencing extreme negative stock returns.

\section{H2: $\quad$ Stock price crashes being higher for stock acquisitions is confined to the sample of overvalued acquirers.}

While overvaluation is an essential determinant of stock price crash risk, the link between the two can be explained by other factors. One such explanation is the bidder's confidence in the acquisition (or lack thereof). As explained by Rappaport and Sirower (1999), a confident acquirer would pay for the acquisition with cash so that its shareholders would not have to share any of the anticipated gains from the purchase with the target firm's 
shareholders. Conversely, should the expected level of synergy be uncertain, the acquirer would hedge its bet by offering stock thereby limiting its shareholders' loss should the venture disappoint. Based on these explanations, the likelihood of a stock crash risk increases with an unsuccessful acquisition that, in turn, was financed by stock.

Another possibility is that a share issue to the target firm shareholders increases the number and diversity of shareholders in the acquiring company post-acquisition. This may force the acquirer to allocate board seats to spokespersons of the target firm shareholders, and to provide them with veto power over future strategic decisions. Note that there is currently a push by regulators (for instance, by the SEC following the 2010 U.S. Dodd-Frank financial reform legislation) as well as activist groups to embolden large shareholders to nominate their directors. With the increase both in the diversity and number of shareholders, there may be extra pressure on the acquiring firm's managers to deliver value promptly, for example, focusing more on the bottom line and the release of quarterly earnings figures in the short- to medium term. Fox and Lorsh (2012) argue that meddling and second-guessing from shareholders are making it even harder for managers to do their jobs effectively. As a result, management focus may be diverted from creating long-term sustainable value toward shortterm but unsustainable gains, using methods like earnings management. Such short-term pressures could end up adding to the stock price crash risk (Francis et al. (2016) find earnings management to be positively correlated with crash risk).

Stock acquisitions may also be followed by stock price crash risk due to the actions of disapproving shareholders selling their newly gained shares. Target shareholders who are mindful of the takeover and who were reluctant to accept the bidder's shares are likely to sell their shares. Though they will wait for the acquisition to be completed to benefit from the premium that usually accompanies M\&As or favorable conversion ratio of theirs for the acquirer's shares; they will subsequently look to sell the shares. Unlike the shareholders of 
acquiring firms, those of the selling firms tend to benefit from robust judicial doctrines and statutory provisions (Afsharipour, 2011) and, therefore, are less likely to suffer losses while waiting for the acquisition to be completed.

These alternative explanations are not necessarily mutually exclusive with the overvaluation hypothesis we focus on in our study, and are left to future research for further analysis.

\section{Public versus Private Targets}

Not all stock offers are associated with poor performance, which would exacerbate the stock price crash risk. Indeed, Chang (1998) documents that the performance of stock offers depends on the type of target acquired. Specifically, Chang finds that stock offers of private (public) targets are associated with positive (negative) abnormal return since they are akin to private placements (public offerings) of equity. The willingness of the private target owner to accept the acquirer stock as a payment method signals both the confidence of the private target owner in the acquirer's future stock price performance and the creation of a blockholder who has strong incentive to monitor the acquiring firm management. In this way, we expect the increase in stock price crash risk among stock-financed acquisitions to be confined to publicly-traded targets.

H3: $\quad$ Stock price crash risk is positively associated with stock acquisitions only among public targets

\section{Acquirers' Profitability}

Park (2003) argues that profitable firms are unlikely to engage in M\&As since they are already generating high returns from their existing operations, while unprofitable firms are keener to consider M\&As. The author finds this attitude toward M\&A based on firm profitability to be consistent with the prospect theory, whereby managers at low-profit firms 
are more prone to chase high-risk ventures in search of profits ${ }^{5}$. In contrast, then, the highprofit acquirers would be less prone to riskier investments, and this positive signal regarding the prospect of the acquisition may counteract the negative signal associated with stock being the method of payment. In consequence, we hypothesize that the positive relationship between stock as the payment method and an acquirer post-M\&A stock price crash risk is confined to the low-profit subsample of acquirers.

H4: $\quad$ Stock price crashes being higher for stock acquisitions is confined to the sample of low-profit acquirers

We test the effect of the acquirer's debt-to-asset ratio as a proxy of the acquirer's financial leverage. If we accept the Black-Merton-Scholes (Black and Scholes, 1973) view of equity as a call option on firm assets with debt as the exercise price, an increase in debt reduces the moneyness of the option and increases the benefits of taking risks ${ }^{6}$. Combining the financial distress that accompanies high debt ratios with the agency issues associated with the usage of stock as an M\&A currency, we hypothesize that financial leverage in stock-forstock mergers would lead to higher post-M\&A bidder's stock price crash risk relative to cashfor-stock mergers.

\section{H5: $\quad$ Stock price crashes being higher for stock acquisitions is confined to the sample of high leverage acquirers.}

\section{Financial Crisis}

\footnotetext{
${ }^{5}$ Managers of underperforming acquirers may act as if being long an out-of-the-money call option; depending on their compensation packages, that may literally be the case.

${ }^{6}$ Vega of an option is highest if it is "at-the-money".
} 
The likelihood of a stock price crash increases during a stock market crisis period ${ }^{7}$. At a time when most stocks are declining, stock acquirers are less likely to pursue value-destroying M\&As, as the likelihood of their shares being overvalued is lower during a crisis period (also see Rhodes-Kropf and Viswanathan, 2004). Thus, it is necessary to examine the subsample of M\&As coinciding with a financial crisis separately from the non-crisis period. To the extent that acquirers' stock price crash risk is driven by the M\&A rather than the financial crisis, we should observe stock price crash risk during the non-crisis period.

\section{H6: $\quad$ Stock acquirers' stock price crash risk is not higher than that of cash acquirers during a period of financial crisis.}

\section{Sample and Methodology}

\section{Sample}

Our sample includes domestic mergers and acquisitions of private and public targets performed by U.S. public corporations. Our sample period starts in 1985 and ends in 2015. The deal minimum value is $\$ 10$ million. We obtain stock return data from the Center for Research in Security Prices (CRSP) database to compute stock price crash risk. Our sample includes the 2007-2009 financial crisis period. We gather financial data from the Compustat database. Firms with a year-end share price less than $\$ 1$ and those with fewer than 26 weeks of return data are excluded to eliminate the effects of thinly traded stocks. Firms with SICs 4900-4999 (i.e., utilities) and 6000-6999 (i.e., financial institutions) are also excluded since

\footnotetext{
${ }^{7}$ Note that we are explicitly denoting only the period 2007-2009 as a financial crisis. Events of lesser magnitude (Savings and Loan crisis, Long Term Capital Management, bursting of the Dot-Com Bubble, etc.) are classified as non-crisis periods.
} 
they operate in highly regulated industries. The final sample includes 6,926 announced and completed deals.

\section{Acquirer Stock Crash Risk Change}

We construct three measures of acquirer-specific crash risk, i.e., $N C S K E W, D U V O L$, and COUNT. The first two measures are derived from Kim, Li and Li (2014), while the third measure follows $\mathrm{An}, \mathrm{Wu}$ and $\mathrm{Wu}$ (2016). To obtain NCSKEW and DUVOL, we first estimate the following expanded market model regression to allow for nonsynchronous trading:

$$
r_{j, t}=\alpha_{j}+\beta_{1, j} r_{m, t-2}+\beta_{2, j} r_{m, t-1}+\beta_{3, j} r_{m, t}+\beta_{4, j} r_{m, t+1}+\beta_{5, j} r_{m, t+2}+\varepsilon_{j, t}
$$

where $r_{j, \tau}$ is the return on stock $j$ in week $\tau$, and $r_{m, \tau}$ is the return on the CRSP valueweighted market index in week $\tau$. The firm-specific weekly return for firm $\mathrm{j}$ in week $\tau\left(\mathrm{W}_{\mathrm{j}, \tau}\right)$ is calculated as the natural logarithm of one plus the residual return from Equation 1.

$N C S K E W$ is the negative conditional skewness of firm-specific weekly returns over a year. It is obtained by taking the negative of the third moment of the firm-specific weekly returns for every year and normalizing it by the standard deviation of firm-specific weekly returns raised to the third power. Specifically, for each firm $\mathrm{j}$ in year $\mathrm{t}, N C S K E W$ is calculated as:

$$
\operatorname{NCSKEW}_{\mathrm{j}, \mathrm{t}}=-\frac{\mathrm{n}(\mathrm{n}-1)^{\frac{3}{2}} \sum \mathrm{W}_{\mathrm{j}, \tau}^{3}}{(\mathrm{n}-1)(\mathrm{n}-2)\left(\sum \mathrm{W}_{\mathrm{j}, \tau}^{2}\right)^{\frac{3}{2}}}
$$

where $\mathrm{W}_{\mathrm{j}, \tau}$ is firm-specific weekly return as defined above, and $\mathrm{n}$ is the number of weekly returns during year $t$. The negative sign associates a higher value of $N C S K E W$ with higher crash risk. 
$D U V O L$ is the down-to-up volatility measure of the crash likelihood. In each year $t$ and for each firm $j$, the firm-specific weekly returns are separated into two groups, i.e. "down" and "up" weeks. "Down" weeks contain weekly returns that are below the annual mean. "Up" weeks contain weekly returns that are above the annual mean. DUVOL is the natural logarithm of the ratio of the standard deviation in the "down" weeks to the standard deviation in the "up" weeks as follows:

$$
\operatorname{DUVOL}_{j, t}=\log \left\{\frac{\left(n_{u}-1\right) \sum_{D o w n} W_{j, \tau}^{2}}{\left(n_{d}-1\right) \sum_{U p} W_{j, \tau}^{2}}\right\}
$$

where $n_{u}$ and $n_{d}$ are the number of up and down weeks in year $t$. A higher value of $D U V O L$ indicates greater crash risk.

Following An, Wu and $\mathrm{Wu}$ (2016), COUNT is the number of crashes minus the number of jumps in year $t$. A crash (jump) occurs when the firm-specific weekly return is 3.09 standard deviations below (above) its mean over fiscal year $\mathrm{t}$.

\section{Regression Models}

To examine the changes in the acquirer's firm-specific stock price crash risk around the M\&A announcement date, we estimate the following model:

$$
\begin{aligned}
\triangle \text { CRASH }_{j, t}= & \beta_{0}+\beta_{1} \text { STOCK }_{\mathrm{j}, t}+\beta_{2} \text { PRIVATE }_{j, t} \\
& +\beta_{3} \ln \operatorname{DEALVALUE}_{j, t} \\
& +\beta_{4} \operatorname{SIZE}_{j, t}+\beta_{5} \text { RELATED }_{j, t}+\beta_{6} \operatorname{COMPETING}_{j, t}+\beta_{7} \text { HOSTILE }_{j, t} \\
& +\beta_{8} \operatorname{TGTROA}_{t-1}+\beta_{9} \operatorname{ACQMKBK}_{j, t-1}+\beta_{10} \text { ACQROA }_{j, t-1} \\
& +\beta_{11} \operatorname{ACQDEBT}_{j, t-1}+\beta_{12} \operatorname{STDEV}_{j, t-1}+\beta_{13} \operatorname{TURNOVER}_{j, t-1} \\
& +\beta_{14} \text { AVGRET }_{j, t-1}+\beta_{15} \text { WAVE }_{t}+\beta_{16} \text { BULL }_{t}+\beta_{17} \operatorname{INDCON}_{t}+\varepsilon_{j, t}
\end{aligned}
$$


where the dependent variable $\triangle C R A S H$ is proxied by changes in either NCSKEW, DUVOL or COUNT from year $t-1$ to $t+1$ relative to the year $t$, i.e. the year of the M\&A announcement. Our primary independent variable is $S T O C K$. It can either be a dummy variable for stock acquirers or the percentage of the deal value that is paid in stock in alternate regressions. To provide support for Hypothesis H1, we expect STOCK to be positively and significantly related to $\triangle C R A S H$.

We control for several deal and bidder characteristics that could affect the acquirer's stock price crash risk as follows. PRIVATE is a dummy variable representing private targets. LNDEALVALUE is the natural log of the deal value. SIZE is the acquirer's market capitalization measured at the end of fiscal year $t-1$. RELATED is a dummy variable representing deals in the same sector using Fama-French 48 sector classification (Fama and French, 1997). ${ }^{8}$ COMPETING is a dummy variable representing bids contested by two or more bidders. HOSTILE is a dummy variable representing unsolicited deals. TGTROA is the target's industry-adjusted return on assets at the end of the preceding fiscal year. ${ }^{9}$ $A C Q M K B K, A C Q R O A$ and $A C Q D E B T$ are the acquirer's industry-adjusted market-to-book ratio, return on asset and total debt-to-asset ratio at the end of the preceding fiscal year. Following Kim, Li and Li (2014) we also account for the following control variables. STDEV is the standard deviation of firm-specific weekly returns estimated from equation (1) in fiscal year $t-1$. TURNOVER is the average weekly share turnover over the current fiscal year minus that of the previous fiscal year. The weekly share turnover is calculated as the weekly

\footnotetext{
8 Data are available at http://mba.tuck.dartmouth.edu/pages/faculty/ken.french/Data_Library/det 48 ind port.html.

${ }^{9}$ Since $50 \%$ of our sample include acquisitions of privately-held targets, the data on target's ROA are not readily available. Thus, we include this variable in one regression specification to make sure our results still hold, and leave it out of subsequent models.
} 
trading volume divided by the total number of shares outstanding during the month of the week. $A V G R E T$ is the average of firm-specific weekly returns estimated from equation (1) in fiscal year $t-1$.

$W A V E$ is the dummy variable equal to 1 for merger wave and 0 otherwise. Following Harford (2005), we calculate the highest 24-month concentration of merger bids for each industry. For each decade (i.e., 120-month period), we simulate 1,000 such distributions whereby each bid is randomly assigned to a month with a probability of $1 / 120$. We calculate the highest 24-month concentration for each simulated distribution. The empirical distribution of the simulated 24-month concentrations is then compared with the actual concentration. A WAVE occurs when the actual peak concentration exceeds the 95th percentile of the distribution.

Next, following Bhardwaj and Brooks (1993) and Kim and Burnie (2002) we classify an announcement month as a bull (bear) month if the CRSP value-weighted index return in that month is higher (lower) than the median market return over the entire period. BULL is the dummy variable equal to 1 for bull market month and 0 otherwise. INDCON is the Herfindahl sales-based acquirer industry concentration in the preceding fiscal year. Since the $B U L L$ and $W A V E$ variables are likely correlated with year fixed effects, we only control for year fixed effects in regression specifications in which these two variables are not included. Similarly, since INDCON is likely correlated with industry fixed effects, we only control for industry fixed effects in regression specifications in which INDCON is not present. The standard errors are corrected for heteroskedasticity.

\section{Results}

\section{Descriptive Statistics}


Table 1 reports the sample distribution by year. The table shows that the sample peaked in the year 2000 following which the annual number of deals averaged around 200 per year. The sample is reasonably equally split between private and public targets $(42.5 \%$ $57.5 \%$ ). Stock deals represent $69.40 \%$ of the sample; cash-only deals represent $26.03 \%$ of the sample. The percentages of hostile, competing and related deals are low and constitute less than $5 \%$ of the sample in each case. Regarding the distribution of the 48 sectors, Business Services are the largest and account for $20 \%$ of the sample size.

\section{[INSERT TABLE 1 ABOUT HERE]}

Table 2 provides descriptive statistics for the variables used in our analysis. The mean negative conditional skewness of acquirer-specific stock returns (NCSKEW) of the acquirer is -0.023 ; the mean down-to-up volatility measure $(D U V O L)$ is -0.06 and the mean COUNT is 0.023. The mean value of the acquirer market-to-book value is 4.295 , and its standard deviation is 5.074 . The mean value of the acquirer's return on assets is $0.023 \%$. The mean acquirer's debt ratio is $45.5 \%$. The average change in weekly trading volume (as a percentage of the monthly shares outstanding) is 0.018 . The average firm in our sample has a firmspecific weekly return of $-0.009 \%$ with weekly firm-specific return volatility of $1.141 \%$.

\section{[INSERT TABLE 2 ABOUT HERE]}

In Panel B of Table 2, we separate cash-only deals from deals involving stock as part of the method of payment. In univariate tests, we find both the mean and median measures of bidders' overvaluation, i.e., MKBK to be significantly higher in deals involving stock than deals that are settled in cash only, by 1.242 and 0.276 , respectively.

\section{Stock Acquirers and the Change in Their Stock Price Crash Risk}

Table 3 reports the results from the regression analysis of the change in stock price crash risk from before to after the M\&A as the dependent variable. The main 
explanatory/independent variable of interest is the dummy variable for stock acquirers (STOCK). Considering the overall sample, the coefficient of STOCK is positive and statistically significant at least at the 5\% level in the regressions of changes in NCSKEW and DUVOL (Panels A and B, respectively). The variable is positive and significant at the $10 \%$ level in the regression of changes in COUNT (Panel C). These findings suggest that stock acquirers experience a significantly larger increase in their stock price crash risk from the year preceding the M\&A to the year following the M\&A, relative to all-cash deals.

\section{[INSERT TABLE 3 ABOUT HERE]}

The coefficients on the control variables reveal the following results. The stock price crash risk is of a lesser concern for firms that acquire targets in their sector (based on the overall sample). The dummy variable RELATED is negative and statistically significant in Panel C. A merger of related firms enables the combined entity to strengthen its market position as well as benefit from economies of scale and scope. The coefficient of TGTROA (representing the target firm's ROA) is positive and statistically significant in Panels A and $\mathrm{B}$, suggesting that the higher the profitability of the target firm going in the M\&A, the lower the rise in stock price crash risk post-M\&A.

Acquirer's market-to-book ratio, $M K B K$, proxies for the acquirer's stock overvaluation. The $M K B K$ coefficient is positive and marginally significant using the change in $D U V O L$, and insignificant for the other two crash risk proxies. This indicates that the informativeness of bidder (over)valuation is at least partly subsumed by other variables, including whether the payment includes bidder stock.

Debt increases the risk of bankruptcy and therefore stock price crash risk. Consistent with this assertion, the coefficient of the acquirer's $D E B T$ ratio is positive and statistically significant in the regressions of changes in NCSKEW and DUVOL. We also find that stock 
price crash risk is positively related to the standard deviation of firm-specific weekly returns (STDEV); weekly turnover pre-merger average returns of the buyer's shares (TURNOVER); the average of firm-specific weekly returns (AVGRET); and, during merger waves (WAVE), albeit only in Panel A. Thus, in as much as bidder motivation for using stock as a method of payment is suspect, it is more likely to be a negative when the market for bidder stock has been particularly "hot". Overall, the results in Table 3 suggest that stock acquirers are associated with increases in acquirers' stock price crash risk.

\section{Issues of Endogeneity and Self-Selection Bias}

Our analysis so far suggests a positive association between increases in measures of stock price crash risk and stock as a method of payment. However, the potential endogenous relation between stock acquisitions and crash risk may affect our results. Endogeneity can arise due to unobservable heterogeneity when unobservable firm-specific factors affect both stock-financed acquisitions and changes in crash risk. It is also likely that acquirers with high stock price crash risk intentionally choose stock as their M\&A currency.

To mitigate these concerns, we use Heckman's (1979) two-stage self-selection approach. In the first stage, we estimate a probit model for the probability that the acquirer will choose to pay with stock after controlling for the current year stock crash risk and several firm and deal characteristics. As an exclusion restriction we use the percentage of deals in the preceding year that was paid with stock; as a de facto instrument, it is likely to affect a bidder's decision to use stock, but not the bidder's specific crash risk. We obtain the predicted probability from the probit model and calculate the Inverse Mills ratio (which we use as a control variable in the second stage regressions). We report the probit regression results in Table 4. All the proxies of stock price crash risk, i.e., NCSKEW, DUVOL, and COUNT are negatively and significantly related to the likelihood of using stock as the M\&A 
currency. This result suggests that the increase in the acquirer's stock crash risk observed among stock acquisitions in Table 3 is not driven by the high pre-acquisition crash risk acquirers. Indeed, acquirers with high pre-acquisition crash risk are less likely to use stock as a method of payment, which has lost its appeal among target shareholders (consistent with Dong et al., 2006). Furthermore, our proxy for overvaluation, i.e., MKBK, which represents the market-to-book value, is positively and significantly related to the likelihood of using stock as the M\&A currency. This finding is in line with the expectation that overvalued bidders would favor stock as the method of payment in M\&As.

\section{[INSERT TABLE 4 ABOUT HERE]}

We report the results from the second stage regressions of the changes in acquirer stock price crash risk in Table 5. The coefficients representing the Inverse Mills ratios from the first stage (probit) regressions are not statistically significant, which limit the adverse effects of the self-selection bias and endogeneity issues on our findings. Consistent with the results in Table 3, the coefficient on the $S T O C K$ variable is positively and significantly related to all three measures of changes in stock price crash risk, confirming significant increases in stock crash risk among stock acquirers in the year following the acquisitions. We include Inverse Mills ratios from Table 4 regressions in all subsequent models/tables/analyses as well.

\section{[INSERT TABLE 5 ABOUT HERE]}

\section{Percentage of the Deal Value Paid in Stock}

In order to further test the relationship between M\&A payment method and acquirer stock crash risk, we replace the dummy variable representing stock-financed acquisitions by the percentage of the deal value paid in stock and rerun the regressions. We present our findings in Table 6 . Should stock as the M\&A currency be the cause of the price crash risk in 
the acquirer's stock, then we would expect the risk to be positively correlated with the percentage of stock payment. Indeed, the findings in Table 6 support the presence of such a relationship. The independent variable PCTSTOCK represents the percentage of the deal value paid in acquirer's shares. Its coefficient is positive and statistically significant at the $5 \%$ level in each of the regressions of $\triangle N C S K E W, \triangle D U V O L$ and $\triangle C O U N T$. Thus, the higher the percentage of stock used as the method of payment in M\&As, the higher is the increase in the acquirer's stock price crash risk.

\section{[INSERT TABLE 6 ABOUT HERE]}

\section{Overvalued versus Undervalued Acquirers}

The essence of our argument is that stock-financed M\&As signal to investors that the bidder's stock is overvalued. Thus, investors penalize stock acquirers, which increases the acquirers' stock price crash risk. In this section, we test the effect of acquirers' stock overvaluation on the increases in price crash risk following the M\&A. Using the industryadjusted market-to-book ratio to proxy for share overvaluation, we separate the sample into two groups (e.g., low valuation vs. high valuation) based upon the sample median industryadjusted market-to-book ratio of the bidder in the year preceding the acquisition. We then run regression equation (4) on each subsample separately and present our findings in Table 7.

\section{[INSERT TABLE 7 ABOUT HERE]}

In Table 7, Models 1, 2, and 3 show the results of the regressions of $\triangle N C S K E W$, $\triangle D U V O L$ and $\triangle C O U N T$, respectively. Each model in Panel A is split into two subsamples: low valuation versus high valuation. We only present the findings of the coefficient of the STOCK variable, i.e., the dummy variable representing stock acquirers, which is our main variable of interest. The coefficient of STOCK is consistently positive and statistically significant in the subsample of acquirers with higher industry-adjusted market-to-book ratio 
only, irrespective of the measure of stock price crash risk; the dummy variable loses its significance in the subsamples of acquirers with the lower industry-adjusted market-to-book ratio. Thus, the likelihood of a stock price crash risk increases if the payment includes acquirer stock, but only among overvalued acquirers, reflecting a market correction of the pre-acquisition overvaluation.

\section{Public versus Private Targets}

In Panel B of Table 7 we split the sample into public versus private targets and reestimate our regression model from Equation (4). The dummy variable representing stock acquirers has a coefficient that is positive and statistically significant at the $5 \%$ level for all changes in stock price crash risk in the acquisitions of public targets; it becomes insignificant in all subsamples involving private targets. This evidence suggests that extreme adverse investors' reaction to acquirer's stock is concentrated among acquisitions of public targets; it is consistent with our hypothesis that among deals for private targets the creation of a sophisticated blockholder negates the bidder overvaluation fears.

\section{Less Profitable versus More Profitable Acquirers}

$\mathrm{H} 4$ postulates that low-profit acquiring firms are risk-seeking and, as a result, their stock prices are likely to crash post-M\&A. Panel C of Table 7 separates the sample into two groups (less profitable vs. more profitable) based on the sample median industry-adjusted return on asset (ROA) of the acquirer in the year preceding the acquisition. The coefficient of the STOCK dummy variable is positive and statistically significant in the subsample of acquirers with lower industry-adjusted ROA only, irrespective of the measure of stock price crash risk. Thus, consistent with Park (2003) and the prospect theory, low-profit acquirers undertake more risky acquisitions as reflected by their higher stock price crash risk postM\&A. 


\section{Low-Leverage versus High-Leverage Acquirers}

To test the moderating effect of the likelihood of financial distress on the relationship between payment method and post-M\&A acquirer crash risk, we separate the sample into two groups based upon the sample median industry-adjusted debt-to-asset ratio of the acquirer in the year preceding the acquisition. The findings from the low leverage and high leverage subsamples are presented in Panel D of Table 7. The coefficient of the STOCK dummy variable is positive and statistically significant in the subsample of acquirers with higher industry-adjusted debt-to-asset ratio only, irrespective of the measure of stock price crash risk. Thus, consistent with $\mathrm{H} 5$, the likelihood of a stock price crash risk increases with highly levered acquirers only.

\section{Crisis versus Non-Crisis Periods}

The likelihood of a stock price crash increases during a financial crisis. At the same time, lower acquirer valuations reduce the likelihood that stock acquirers would pursue valuedestroying M\&As due to their stocks being overvalued (Rhodes-Kropf and Viswanathan, 2004). It is therefore important to examine the subsample of M\&As taking place during a financial crisis separately, to see the net effect of those two factors on the relationship between stock acquisitions and stock crash risk. Since our sample coincides with the well documented 2007-2009 financial crisis, we analyze these three years separately from the rest of the sample.

In Panel E Table 7, Models 1, 2 and 3 show the results of the regressions of $\triangle N C S K E W, \triangle D U V O L$ and $\triangle C O U N T$, respectively, as was the case in the preceding panels. Each model is split into two subsamples, i.e., the non-crisis period versus the crisis period. The coefficient of STOCK is consistently positive and statistically significant during the noncrisis years irrespective of the measure of stock price crash risk. Conversely, the dummy 
variable loses its significance during the crisis years. This supports our hypothesis that stock acquisitions do not signal greater stock crash risk when the overall stock market is in severe decline.

\section{Robustness Checks}

In Table 8 we find that greater stock crash risk for stock acquirers is confined to the subsample of overvalued acquirers. It is possible that mere overvaluation is causing the stock crash risk to rise, rather than acting on via a stock-financed acquisition. If so, we should see increased stock crash risk among overvalued firms, regardless of whether the firm makes an acquisition or not. One way to isolate the effect of stock acquisitions from overvaluation is to look at the difference in the stock crash risk of an overvalued stock acquirer and a similarly overvalued comparable non-acquirer firm during the same time period. We address this in Table 8 .

\section{[INSERT TABLE 8 ABOUT HERE]}

We adjust the dependent variables, i.e., $\triangle N C S K E W, \triangle D U V O L$ and $\triangle C O U N T$ in Models 1, 2 and 3, respectively as follows. In Panel A(B), these dependent variables are adjusted by their respective mean (median) figures of all non-acquiring firms that share the same industry and the same tercile of the market-to-book ratio from year $\mathrm{t}-1$. The coefficients on our main variable of interest, i.e., the dummy for stock acquisitions, remain positive and statistically significant regardless of the crash risk proxy used. We therefore conclude that while the overvaluation may help determine the payment method, the act of (stock) acquisition itself increases acquirer's subsequent crash risk. 
Another possible issue with the robustness of our results lies in our models' reliance on pre-merger accounting data (the data is from year $t-1$ where year $t$ is the announcement year). This is a common feature of corporate finance literature. Weiß et al. (2014) relate changes in bank post-merger systemic risk (six months after the merger) to pre-merger accounting characteristics; Filson and Olfati (2014) do this for both systematic and unsystematic risk one year after a merger. Similarly, Vallascas and Hagendorff (2011) relate the change in Merton's (1974) distance to default six months out to pre-merger characteristics. Perhaps most pertinently to the issue at hand, Furfine and Rosen (2011) regress change in default risk (based on Merton's distance to default) six months post-merger on both pre-merger characteristics and post-merger acquirer stock movement; post-merger acquirer stock movement is insignificant in their models.

Nonetheless, there exists the possibility that post-merger changes to acquiring firms may bias our results. We address this issue by running a two-stage regression in Table 9. In Stage 1 we regress our main dependent variables, our proxies for crash risk change, on various changes in firm characteristics from year $t-1$ to year $t(t$ being the year of the merger announcement). We then extract the residuals from this first stage and regress them (e.g. the portion of the crash risk change that is not explained by the changes in firm characteristics) on the merger specific characteristics, including our primary variable on interest, the dummy for stock acquisitions. The STOCK dummy remains positive and significant, suggesting that stock acquisitions do indeed result in higher post-merger crash risk than all-cash deals.

\section{[INSERT TABLE 9 ABOUT HERE]}

Another potential problem in using bidder and deal characteristics in the same regression model is the need to account for the relationship between the two. For instance, an overvalued bidder (proxied by its market-to-book ratio, a bidder characteristic) is likely to use 
stock (i.e., a deal characteristic) as the method of payment. To deal with this problem, Table 9 uses the method of orthogonalization ${ }^{10}$. We regress bidders' stock price crash risk measures on bidders' characteristics (including bidder's market-to-book ratio) in a first-stage regression. The residuals from the first stage regression are then used as the dependent variable in a second-stage regression to be regressed on the deal characteristics, including the method of payment. This procedure allows us to separate the effects of the deal characteristics from the bidder characteristics in examining the bidder's stock price crash risk. As mentioned earlier, the coefficient of the dummy variable representing deals financed by stock remains positive and significant, which suggests that the portion of the increases in stock price crash risk which is not explained by bidder characteristics is positively associated with stock as the method of payment.

\section{Conclusion}

This study examines whether stock-financed acquisitions contribute to acquirers' stock price crash risk. Agency issues and investors' perception that acquirers are more likely to use their shares as the M\&A currency when they are overvalued suggest that these acquirers will experience higher price crash risk in their stock following an M\&A relative to all-cash acquisitions. We use three proxies to estimate stock price crash risk: the negative conditional skewness of acquirer-specific stock returns, a down-to-up volatility measure, and the excess of extreme negative stock returns over extreme positive returns.

We find that acquirers experience significantly higher stock price crash risk when they acquire targets with stock as opposed to cash. The change in risk is positively associated with the percentage of stock used to finance the deal. Consistent with the overvaluation

\footnotetext{
10 See, for example, Ali Nejadmalayeri et al. (2017) and Kahn and Liñares-Zegarra (2016) for use of orthogonalization in empirical finance research
} 
hypothesis, we find that changes in acquirers' stock price crash risk are concentrated among overvalued acquirers, i.e., those with a positive industry-adjusted market-to-book ratio. We confirm that it is the acquisition act rather than mere overvaluation that is driving our results. This phenomenon exists in acquisitions of public targets, among less profitable and highly leveraged acquirers, and during non-financial-crisis years. The findings persist after we control for potential endogeneity issues, in particular self-selection bias by stock acquirers, as well as post-merger changes to the acquiring firm. Overall, the new evidence documented in this study supports the agency theory and overvaluation hypothesis in stock-financed M\&A deals. 


\section{References}

Afsharipour, A., 2011. A Shareholders' Put Option: Counteracting the Acquirer Overpayment Problem. Minn. L. Rev., 96, p.1018.

Akbulut, M. E. (2013). Do overvaluation-driven stock acquisitions really benefit acquirer shareholders? Journal of Financial and Quantitative Analysis, 48(4), 1025-1055.

Alexandridis, G., Mavrovitis, C. F., \& Travlos, N. G. (2012). How have M\&As changed? Evidence from the sixth merger wave. The European Journal of Finance, 18(8), 663-688.

Allen, L., Jagtiani, J., Peristiani, S. and Saunders, A. (2004). 'The role of bank advisors in mergers and acquisitions. Journal of Money Credit and Banking, 36, 197-224.

An, H., Wu, Q., \& Wu, Z. (2016). REIT crash risk and institutional investors. The Journal of Real Estate Finance and Economics, 53(4), 527-558.

Ang, J. S., \& Cheng, Y. (2006). Direct evidence on the market- driven acquisition theory. Journal of Financial Research, 29(2), 199-216.

Arikan, A. M., \& Stulz, R. M. (2016). Corporate acquisitions, diversification, and the firm's life cycle. The Journal of Finance, 71(1), 139-194.

Baker, M., R. S. Ruback and J. Wurgler, 2007, "Behavioral Corporate Finance," in B. E. Eckbo (Ed.), Handbook of Corporate Finance: Empirical Corporate Finance, vol. 1, Chapter 4 (Elsevier/North-Holland, Handbooks in Finance Series).

Ben-David, I., Drake, M. S., \& Roulstone, D. T. (2015). Acquirer valuation and acquisition decisions: identifying mispricing using short interest. Journal of Financial and Quantitative Analysis, 50(1-2), 1-32.

Betton, S., Eckbo, B. E., \& Thorburn, K. S. (2008). Corporate takeovers. Handbook of corporate finance: Empirical corporate finance, 2, 291-430.

Bhardwaj, R. and Brooks, L. (1993). Dual betas from bull and bear market: Reversal of the size effect, Journal of Financial Research 16, 269-283.

Black, F., \& Scholes, M. (1973). The pricing of options and corporate liabilities. Journal of political economy, 81(3), 637-654.

Bowers, H. M., Moore, N. H., \& Tse, K. M. (2000). Signaling, financial slack and corporate acquisitions. Review of Quantitative Finance and Accounting, 15(3), 195-216.

Brown, D. T., \& Ryngaert, M. D. (1991). The mode of acquisition in takeovers: Taxes and asymmetric information. The Journal of Finance, 46(2), 653-669.

Campello, M., Graham, J. R., and Harvey, C. R., 2010. The real effects of financial constraints: Evidence from a financial crisis. Journal of Financial Economics 97(3): 470-487.

Chen, J., Hong, H., \& Stein, J. C. (2001). Forecasting crashes: Trading volume, past returns, and conditional skewness in stock prices. Journal of financial Economics, 61(3), 345-381.

Chidambaran, N. K., John, K., Shangguan, Z., \& Vasudevan, G. (2010). Hot and cold merger markets. Review of Quantitative Finance and Accounting, 34(3), 327-349. 
Dong, M., Hirshleifer, D., Richardson, S., \& Teoh, S. H. (2006). Does investor misvaluation drive the takeover market?. The Journal of Finance, 61(2), 725-762.

Erel, I., Liao, R. C., \& Weisbach, M. S. (2012). Determinants of cross-border mergers and acquisitions. The Journal of Finance, 67(3), 1045-1082.

Fama, E. and French, K., (1997). Industry costs of equity. Journal of Financial Economics 43 (2), 153- 193.

Filson, D., \& Olfati, S. (2014). The impacts of Gramm-Leach-Bliley bank diversification on value and risk. Journal of Banking \& Finance, 41, 209-221.

Fox, J., \& Lorsch, J. W. (2012). What Good Are Shareholders? Harvard Business Review. Accessed at: https://hbr.org/2012/07/what-good-are-shareholders

Francis, B., Hasan, I., \& Li, L. (2016). Abnormal real operations, real earnings management, and subsequent crashes in stock prices. Review of Quantitative Finance and Accounting, $46(2), 217-260$.

Fu, F., Lin, L., \& Officer, M. S. (2013). Acquisitions driven by stock overvaluation: Are they good deals?. Journal of Financial Economics, 109(1), 24-39.

Furfine, C. H., \& Rosen, R. J. (2011). Mergers increase default risk. Journal of Corporate Finance, 17(4), 832-849.

Harford, J. (1999). Corporate cash reserves and acquisitions. Journal of Finance, 54, 19691997.

Harford, J. (2005). What drives merger waves? Journal of Financial Economics 77(3), 529560 .

Harvey, C. R., \& Siddique, A. (2000). Conditional skewness in asset pricing tests. The Journal of Finance, 55(3), 1263-1295.

He, Guanming and Ren, Helen, Financial Constraints and Future Stock Price Crash Risk (August 17, 2017). WBS Finance Group Research Paper. Available at SSRN: https://ssrn.com/abstract=3021307 or http://dx.doi.org/10.2139/ssrn.3021307

Heckman, J. J. (1979). Sample selection bias as a specification error. Econometrica, 47(1), 153-161.

Jensen, M. C. (1986). Agency costs of free cash flow, corporate finance, and takeovers. The American economic review, 76(2), 323-329.

Jensen, M. C. (1993). The modern industrial revolution, exit, and the failure of internal control systems. the Journal of Finance, 48(3), 831-880.

Jovanovic, B., \& Rousseau, P. L. (2002). The Q-theory of mergers. American Economic Review, 92(2), 198-204.

Kahn, C. M. and Liñares-Zegarra, J.M., (2016). Identity theft and consumer payment choice: Does security really matter?. Journal of Financial Services Research, 50(1), pp.121-159. 
Kim, M. K., \& Burnie, D. A. (2002). The firm size effect and the economic cycle. Journal of Financial Research, 25(1), 111-124.

Kim, Y., Li, H., \& Li, S. (2014). Corporate social responsibility and stock price crash risk. Journal of Banking \& Finance, 43, 1-13.

Langetieg, T. C., Haugen, R. A., \& Wichern, D. W. (1980). Merger and stockholder risk. Journal of Financial and Quantitative Analysis, 15(3), 689-717.

Lee, W., \& Wang, L. (2017). Do political connections affect stock price crash risk? Firmlevel evidence from China. Review of Quantitative Finance and Accounting, 48(3), 643-676.

Loughran, T, \& Vijh, A. (1997). Do long-term shareholders benefit from corporate acquisitions? Journal of Finance, 52, 1765-1790.

Lys, T., \& Sohn, S. (1990). The association between revisions of financial analysts' earnings forecasts and security-price changes. Journal of Accounting and Economics, 13(4), 341-363.

Maksimovic, V., \& Phillips, G. M. (2013). Conglomerate firms, internal capital markets, and the theory of the firm. Annu. Rev. Financ. Econ., 5(1), 225-244.

Martin, K. J. (1996). The method of payment in corporate acquisitions, investment opportunities, and management ownership. The Journal of finance, 51(4), 1227-1246.

Merton, R. C. (1974). On the pricing of corporate debt: The risk structure of interest rates. The Journal of finance, 29(2), 449-470.

Mitchell, M. L., \& Stafford, E. (2000). Managerial decisions and long- term stock price performance. The Journal of Business, 73(3), 287-329.

Moeller, S. B., Schlingemann, F. P., \& Stulz, R. M. (2005). Wealth destruction on a massive scale? A study of acquiring- firm returns in the recent merger wave. The Journal of Finance, 60(2), 757-782.

Mueller, D. C. (1972). A life cycle theory of the firm. The Journal of Industrial Economics, 199-219.

Nejadmalayeri, A., Iyer, S. R. and Singh, M., (2017). Is there an optimally diversified conglomerate? Gleaning answers from capital markets. Review of Quantitative Finance and Accounting, 49(1), pp.117-158.

Oler, D., \& Waegelein, J. F. (2011). Can long-term performance plans mitigate the negative effects of stock consideration and high cash for acquirers? Review of Quantitative Finance and Accounting, 37(1), 63-86.

Park, C. (2003). Prior performance characteristics of related and unrelated acquirers.

Strategic Management Journal, 24(5), 471-480.

Parvinen, P., \& Tikkanen, H. (2007). Incentive asymmetries in the mergers and acquisitions process. Journal of Management Studies, 44(5), 759-787.

Rappaport, A. and Sirower, M.L., 1999. Stock or cash? The trade-offs for buyers and sellers in mergers and acquisitions. Harvard business review, 77, pp.147-159. 
Rau, P. R., \& Vermaelen, T. (1998). Glamour, value and the post-acquisition performance of acquiring firms. Journal of financial economics, 49(2), 223-253.

Rhodes-Kropf, M., Robinson, D. T., \& Viswanathan, S. (2005). Valuation waves and merger activity: The empirical evidence. Journal of Financial Economics, 77(3), 561-603.

Rhodes - Kropf, M., \& Viswanathan, S. (2004). Market valuation and merger waves. The Journal of Finance, 59(6), 2685-2718.

Savor, P. G., \& Lu, Q. (2009). Do stock mergers create value for acquirers?. The Journal of Finance, 64(3), 1061-1097.

Servaes, H. (1991). Tobin's Q and the Gains from Takeovers. The Journal of Finance, 46(1), 409-419.

Shih, Y. C., \& Hsu, B. J. (2009). Does stock misvaluation differentiate the motives for takeovers? Review of Pacific Basin Financial Markets and Policies, 12(03), 545-566.

Shleifer, A., \& Vishny, R. W. (2003). Stock market driven acquisitions. Journal of financial Economics, 70(3), 295-311.

Song, Weihong, Does Overvaluation Lead to Bad Mergers? (May 2007). AFA 2007 Chicago Meetings Paper. Available at SSRN: https://ssrn.com/abstract $=686507$ or http://dx.doi.org/10.2139/ssrn.686507

Spiess, D. K., \& Affleck-Graves, J. (1995). Underperformance in long-run stock returns following seasoned equity offerings. Journal of Financial Economics, 38(3), 243-267.

Stein, J. C. (1988). Takeover threats and managerial myopia. Journal of political economy, 96(1), 61-80.

Tee, C. M., Yee, A. S. V., \& Chong, A. L. (2018). Institutional Investors' Monitoring and Stock Price Crash Risk: Evidence From Politically Connected Firms. Review of Pacific Basin Financial Markets and Policies, 1850028.

Vallascas, F., \& Hagendorff, J. (2011). The impact of European bank mergers on bidder default risk. Journal of Banking \& Finance, 35(4), 902-915.

Weiß, G. N., Neumann, S., \& Bostandzic, D. (2014). Systemic risk and bank consolidation: International evidence. Journal of Banking \& Finance, 40, 165-181. 
Table 1 - Sample Distribution

This table reports the sample distribution by year, industry and deal characteristics.

\begin{tabular}{|c|c|c|c|c|c|}
\hline Year & $N$ & Percent & Industry & $N$ & Percent \\
\hline 1985 & 55 & 1 & AERO & 66 & 1.2 \\
\hline 1986 & 79 & 1.44 & AGRIC & 12 & 0.22 \\
\hline 1987 & 70 & 1.27 & AUTOS & 63 & 1.15 \\
\hline 1991 & 78 & 1.42 & BEER & 11 & 0.2 \\
\hline 1992 & 105 & 1.91 & BLDMT & 100 & 1.82 \\
\hline 1993 & 132 & 2.4 & BOOKS & 54 & 0.98 \\
\hline 1994 & 169 & 3.07 & BOXES & 5 & 0.09 \\
\hline 1995 & 238 & 4.33 & BUSSV & 1,114 & 20.27 \\
\hline 1996 & 284 & 5.17 & CHEM & 92 & 1.67 \\
\hline 1997 & 320 & 5.82 & CHIPS & 420 & 7.64 \\
\hline 1998 & 362 & 6.59 & CLTHS & 50 & 0.91 \\
\hline 1999 & 357 & 6.5 & CNSTR & 67 & 1.22 \\
\hline 2000 & 412 & 7.5 & COAL & 7 & 0.13 \\
\hline 2001 & 218 & 3.97 & COMPS & 491 & 8.93 \\
\hline 2002 & 178 & 3.24 & DRUGS & 305 & 5.55 \\
\hline 2003 & 205 & 3.73 & ELCEQ & 79 & 1.44 \\
\hline 2004 & 208 & 3.78 & FABPR & 15 & 0.27 \\
\hline 2005 & 226 & 4.11 & FOOD & 78 & 1.42 \\
\hline 2006 & 238 & 4.33 & FUN & 76 & 1.38 \\
\hline 2007 & 238 & 4.33 & GOLD & 103 & 1.87 \\
\hline 2008 & 173 & 3.15 & GUNS & 8 & 0.15 \\
\hline 2009 & 152 & 2.77 & HLTH & 166 & 3.02 \\
\hline 2010 & 157 & 2.86 & HSHLD & 61 & 1.11 \\
\hline 2011 & 171 & 3.11 & LABEQ & 143 & 2.6 \\
\hline 2012 & 152 & 2.77 & MACH & 181 & 3.29 \\
\hline 2013 & 154 & 2.8 & MEALS & 37 & 0.67 \\
\hline 2014 & 179 & 3.26 & MEDEQ & 164 & 2.98 \\
\hline 2015 & 186 & 3.38 & MINES & 33 & 0.6 \\
\hline \multirow[t]{2}{*}{ Total } & 5,496 & 100 & OIL & 318 & 5.79 \\
\hline & & & PAPER & 64 & 1.16 \\
\hline Deal characteristics & $N$ & Percent & PERSV & 40 & 0.73 \\
\hline Private targets & 2,334 & 42.47 & RTAIL & 198 & 3.6 \\
\hline Stock deals & 3,814 & 69.40 & RUBBR & 28 & 0.51 \\
\hline Hostile deals & 40 & 0.70 & SHIPS & 10 & 0.18 \\
\hline Competing deals & 129 & 2.35 & SODA & 12 & 0.22 \\
\hline \multirow{7}{*}{ Related deals } & 251 & 4.57 & STEEL & 85 & 1.55 \\
\hline & & & TELCM & 322 & 5.86 \\
\hline & & & TOYS & 34 & 0.62 \\
\hline & & & TRANS & 106 & 1.93 \\
\hline & & & TXTLS & 25 & 0.45 \\
\hline & & & WHLSL & 181 & 3.29 \\
\hline & & & OTHER & 72 & 1.31 \\
\hline
\end{tabular}


Table 2 - Descriptive Statistics

$N C S K E W$ is the negative conditional skewness of acquirer-specific stock returns; $D U V O L$ is a down-to-up volatility measure; COUNT is the excess of extreme negative stock returns over extreme positive returns. LNDEALVALUE is the natural $\log$ of the deal value. SIZE is the acquirer's market capitalization measured at the end of fiscal year $t-1$. TGTROA is the target's industry-adjusted return on assets. $A C Q M K B K$ is the acquirer's industry-adjusted market-to-book ratio. $A C Q \mathrm{R} O A$ is the acquirer's industry-adjusted return on assets. $A C Q D E B T$ is the acquirer's industry-adjusted total debt-toasset ratio. Following Kim, $\mathrm{Li}$ and $\mathrm{Li}(2014)$ we also account for the following control variables. STDEV is the standard deviation of firm-specific weekly returns estimated from equation (1) in fiscal year $t-1$. TURNOVER is the average weekly share turnover over the current fiscal year minus that of the previous fiscal year. The weekly share turnover is calculated as the weekly trading volume divided by the total number of shares outstanding during the month of the week. $A V G R E T$ is the average of firm-specific weekly returns estimated from equation (1) in fiscal year $t-1$. WAVE is the dummy variable equal to 1 for merger wave and 0 otherwise. $B U L L$ is the dummy variable equal to 1 for bull market month and 0 otherwise. INDCON is the Herfindahl sales-based acquirer industry concentration in the preceding fiscal year. *, ** and $* * *$ indicate the significance levels of $10 \%, 5 \%$ and $1 \%$, respectively.

\begin{tabular}{|c|c|c|c|c|c|c|}
\hline \multicolumn{7}{|c|}{ Panel A-Whole Sample } \\
\hline Variables & $N$ & Mean & Median & $25^{\text {th }}$ percentile & $75^{\text {th }}$ percentile & Standard deviation \\
\hline NCSKEW & 5,495 & -0.023 & -0.073 & -0.453 & 0.338 & 0.777 \\
\hline DUVOL & 5,495 & -0.060 & -0.064 & -0.351 & 0.227 & 0.464 \\
\hline COUNT & 5,495 & 0.023 & 0.000 & 0.000 & 0.000 & 0.609 \\
\hline LNDEALVALUE & 5,496 & 4.845 & 4.613 & 3.526 & 5.914 & 1.671 \\
\hline SIZE & 5,496 & 7.160 & 6.975 & 5.724 & 8.496 & 2.095 \\
\hline TGTROA & 2,926 & -0.084 & 0.026 & -0.083 & 0.082 & 0.442 \\
\hline$A C Q M K B K$ & 5,494 & 4.295 & 2.774 & 1.730 & 4.811 & 5.074 \\
\hline$A C Q R O A$ & 5,490 & 0.023 & 0.053 & 0.010 & 0.093 & 0.157 \\
\hline$A C Q D E B T$ & 5,495 & 0.455 & 0.454 & 0.274 & 0.605 & 0.224 \\
\hline$S T D E V \times 100$ & 5,496 & 1.141 & 0.974 & 0.682 & 1.414 & 0.662 \\
\hline TURNOVER & 5,454 & 0.018 & 0.017 & -0.129 & 0.199 & 1.091 \\
\hline AVGRET $\times 100$ & 5,496 & -0.009 & -0.005 & -0.010 & -0.002 & 0.012 \\
\hline WAVE & 5,496 & 0.429 & 0.000 & 0.000 & 1.000 & 0.495 \\
\hline$B U L L$ & 5,496 & 0.499 & 0.000 & 0.000 & 1.000 & 0.500 \\
\hline$I N D C O N$ & 5,496 & 0.059 & 0.048 & 0.033 & 0.068 & 0.044 \\
\hline
\end{tabular}

Panel B - By Subsamples Based on Method of Payments

\begin{tabular}{lllllllll} 
& \multicolumn{7}{l}{ Stock/Stock-Cash } & \multicolumn{2}{l}{ Cash Only } & \multicolumn{2}{l}{ Difference } \\
Variables & Mean & Median & Mean & Median & Mean & Median & t-stat & Wilcoxon-stat \\
\hline LNDEALVALUE & 4.780 & 4.523 & 5.009 & 4.868 & -0.229 & -0.344 & $-4.58^{* * *}$ & $-5.90^{* * *}$ \\
SIZE & 6.889 & 6.739 & 7.847 & 7.557 & -0.958 & -0.818 & $-15.59^{* * *}$ & $-15.12^{* * *}$ \\
TGTROA & -0.100 & 0.024 & -0.049 & 0.031 & -0.051 & -0.007 & $-2.91^{* * *}$ & $-2.04^{* *}$ \\
ACQMKBK & 4.645 & 2.883 & 3.403 & 2.607 & 1.242 & 0.276 & $8.21^{* * *}$ & $4.89^{* * *}$ \\
ACQROA & 0.008 & 0.046 & 0.061 & 0.065 & -0.052 & -0.019 & $-11.22^{* * *}$ & $-10.92^{* * *}$ \\
ACQDEBT & 0.443 & 0.436 & 0.486 & 0.488 & -0.043 & -0.052 & $-6.37 * * *$ & $-6.94^{* * *}$ \\
STDEV $\times 100$ & 1.261 & 1.097 & 0.837 & 0.749 & 0.425 & 0.347 & $22.37 * * *$ & $23.87^{* * *}$ \\
TURNOVER & 0.028 & 0.026 & -0.007 & 0.005 & 0.035 & 0.022 & $4.07 * * *$ & $4.63^{* * *}$ \\
AVGRET $\times 100$ & -0.010 & -0.006 & -0.004 & -0.003 & -0.006 & -0.003 & $-17.09^{* * *}$ & $-23.88^{* * *}$ \\
WAVE & 0.471 & 0.000 & 0.320 & 0.000 & 0.152 & 0.000 & $10.32^{* * *}$ & $10.23^{* * *}$ \\
BULL & 0.506 & 1.000 & 0.483 & 0.000 & 0.023 & 1.000 & 1.54 & 1.54 \\
INDCON & 0.058 & 0.047 & 0.062 & 0.050 & -0.004 & -0.003 & $-3.20^{* * *}$ & $-2.89 * * *$ \\
\hline
\end{tabular}




\section{Table 3 - Regressions of Change in Acquirer Stock Crash Risk}

The dependent variables are the changes in the acquirer's $\triangle N C S K E W$ (in Model 1), $\triangle D U V O L$ (in Model 2) and $\triangle C O U N T$ (in Panel C) from the year before to the year after the acquisitions. NCSKEW is the negative conditional skewness of acquirer-specific stock returns; DUVOL is a down-to-up volatility measure; COUNT is the excess of extreme negative stock returns over extreme positive returns. STOCK is the dummy variable for stock acquirers. PRIVATE is a dummy variable representing private targets. LNDEALVALUE is the natural log of the deal value. SIZE is the acquirer's market capitalization measured at the end of the preceding fiscal year. RELATED is a dummy variable representing deals in the same sector using Fama-French 48 sector classification. COMPETING is a dummy variable contested by two or more bidders. HOSTILE is a dummy variable representing unsolicited deals. TGTROA is the target's industry-adjusted return on assets at the end of the preceding fiscal year. $A C Q M K B K, A C Q \mathrm{R} O A$ and $A C Q D E B T$ are the acquirer's industry-adjusted market-to-book ratio, return on asset and total debt-to-asset ratio at the end of the preceding fiscal year. Following Kim, Li and $\mathrm{Li}(2014)$ we also account for the following control variables. STDEV is the standard deviation of firm-specific weekly returns estimated from equation (1) at the end of the preceding fiscal year. TURNOVER is the average weekly share turnover over the current fiscal year minus that of the previous fiscal year. The weekly share turnover is calculated as the weekly trading volume divided by the total number of shares outstanding during the month of the week. AVGRET is the average of firm-specific weekly returns estimated from equation (1) at the end of the preceding fiscal year. WAVE is the dummy variable equal to 1 for merger wave and 0 otherwise. $B U L L$ is the dummy variable equal to 1 for bull market month and 0 otherwise. INDCON is the Herfindahl sales-based acquirer industry concentration in the preceding fiscal year. $*, * *$ and $* * *$ indicate the significance levels of $10 \%, 5 \%$ and $1 \%$.

\begin{tabular}{|c|c|c|c|c|c|c|}
\hline \multirow[b]{2}{*}{ Variables } & \multicolumn{2}{|c|}{ Panel $A-\triangle N C S K E W$} & \multicolumn{2}{|c|}{ Panel B - $\triangle D U V O L$} & \multicolumn{2}{|c|}{ Panel C- $\triangle$ COUNTCHG } \\
\hline & Model 1 & Model 2 & Model 1 & Model 2 & Model 1 & Model 2 \\
\hline STOCK & $\begin{array}{l}0.125 \\
(2.640 * * *)\end{array}$ & $\begin{array}{l}0.062 \\
\left(2.288^{* *}\right)\end{array}$ & $\begin{array}{l}0.066 \\
\left(2.320^{* *}\right)\end{array}$ & $\begin{array}{l}0.041 \\
\left(2.140^{* *}\right)\end{array}$ & $\begin{array}{l}0.070 \\
\left(1.902^{*}\right)\end{array}$ & $\begin{array}{l}0.033 \\
\left(1.795^{*}\right)\end{array}$ \\
\hline PRIVATE & $\begin{array}{l}0.057 \\
(0.877)\end{array}$ & $\begin{array}{l}0.020 \\
(0.563)\end{array}$ & $\begin{array}{l}0.019 \\
(0.481)\end{array}$ & $\begin{array}{l}0.026 \\
(1.253)\end{array}$ & $\begin{array}{l}-0.006 \\
(-0.137)\end{array}$ & $\begin{array}{l}-0.005 \\
(-0.207)\end{array}$ \\
\hline LNDEALVALUE & $\begin{array}{l}-0.022 \\
(-1.258)\end{array}$ & $\begin{array}{l}-0.023 \\
\left(-1.891^{*}\right)\end{array}$ & $\begin{array}{l}-0.011 \\
(-1.134)\end{array}$ & $\begin{array}{l}-0.008 \\
(-1.110)\end{array}$ & $\begin{array}{l}-0.012 \\
(-0.937)\end{array}$ & $\begin{array}{l}-0.006 \\
(-0.601)\end{array}$ \\
\hline SIZE & $\begin{array}{l}0.047 \\
(3.052 * * *)\end{array}$ & $\begin{array}{l}0.040 \\
\left(4.256^{* * *}\right)\end{array}$ & $\begin{array}{l}0.016 \\
\left(1.788^{*}\right)\end{array}$ & $\begin{array}{l}0.009 \\
(1.615)\end{array}$ & $\begin{array}{l}0.022 \\
\left(1.906^{*}\right)\end{array}$ & $\begin{array}{l}0.017 \\
(2.305 * *)\end{array}$ \\
\hline RELATED & $\begin{array}{l}-0.105 \\
(-1.562)\end{array}$ & $\begin{array}{l}-0.078 \\
(-1.179)\end{array}$ & $\begin{array}{l}-0.037 \\
(-0.894)\end{array}$ & $\begin{array}{l}-0.031 \\
(-0.761)\end{array}$ & $\begin{array}{l}-0.115 \\
(-2.081 * *)\end{array}$ & $\begin{array}{l}-0.102 \\
(-1.880 *)\end{array}$ \\
\hline COMPETING & $\begin{array}{l}0.122 \\
(1.219)\end{array}$ & $\begin{array}{l}0.095 \\
(1.013)\end{array}$ & $\begin{array}{l}0.092 \\
(1.482)\end{array}$ & $\begin{array}{l}0.065 \\
(1.088)\end{array}$ & $\begin{array}{l}0.040 \\
(0.527)\end{array}$ & $\begin{array}{l}0.032 \\
(0.457)\end{array}$ \\
\hline HOSTILE & $\begin{array}{l}-0.134 \\
(-0.845)\end{array}$ & $\begin{array}{l}-0.177 \\
(-1.214)\end{array}$ & $\begin{array}{l}-0.116 \\
(-1.032)\end{array}$ & $\begin{array}{l}-0.151 \\
(-1.442)\end{array}$ & $\begin{array}{l}-0.019 \\
(-0.153)\end{array}$ & $\begin{array}{l}-0.048 \\
(-0.379)\end{array}$ \\
\hline TGTROA & $\begin{array}{l}0.126 \\
\left(1.864^{*}\right)\end{array}$ & & $\begin{array}{l}0.079 \\
\left(2.251^{* *}\right)\end{array}$ & & $\begin{array}{l}0.045 \\
(1.092)\end{array}$ & \\
\hline$A C Q M K B K$ & 0.000 & 0.001 & 0.000 & 0.001 & 0.000 & 0.001 \\
\hline
\end{tabular}




\begin{tabular}{|c|c|c|c|c|c|c|}
\hline & $(0.834)$ & $(1.574)$ & $(2.158 * *)$ & $(2.427 * *)$ & $(0.416)$ & $(1.156)$ \\
\hline \multirow[t]{2}{*}{$A C Q R O A$} & -0.172 & -0.022 & -0.153 & -0.113 & -0.157 & -0.101 \\
\hline & $(-1.269)$ & $(-0.196)$ & $\left(-1.859^{*}\right)$ & $\left(-1.708^{*}\right)$ & $\left(-1.771^{*}\right)$ & $(-1.385)$ \\
\hline \multirow[t]{2}{*}{$A C Q D E B T$} & 0.197 & 0.132 & 0.107 & 0.091 & -0.026 & -0.051 \\
\hline & $(1.850 *)$ & $(1.882 *)$ & $(1.697 *)$ & $(2.081 * *)$ & $(-0.340)$ & $(-0.979)$ \\
\hline \multirow[t]{2}{*}{$S T D E V \times 100$} & 0.269 & 0.334 & 0.154 & 0.099 & 0.013 & 0.131 \\
\hline & $(2.020 * *)$ & $(4.151 * * *)$ & $\left(1.846^{*}\right)$ & $(2.063 * *)$ & $(0.131)$ & $(2.211 * *)$ \\
\hline \multirow[t]{2}{*}{ TURNOVER × 100} & 0.043 & 0.045 & 0.021 & 0.023 & 0.034 & 0.030 \\
\hline & $\left(2.816^{* * *}\right)$ & $(3.592 * * *)$ & $(2.488 * *)$ & $(3.025 * * *)$ & $(3.666 * * *)$ & $(3.867 * * *)$ \\
\hline \multirow[t]{2}{*}{$A V G R E T \times 100$} & 10.101 & 14.748 & 6.732 & 4.651 & 0.456 & 6.983 \\
\hline & $(1.508)$ & $(3.416 * * *)$ & (1.494) & $\left(1.780^{*}\right)$ & $(0.092)$ & $(2.282 * *)$ \\
\hline \multirow[t]{2}{*}{ WAVE } & & 0.066 & & 0.028 & & 0.036 \\
\hline & & $(2.028 * *)$ & & (1.459) & & (1.497) \\
\hline \multirow[t]{2}{*}{$B U L L$} & & 0.005 & & 0.019 & & -0.016 \\
\hline & & $(0.153)$ & & (1.044) & & $(-0.677)$ \\
\hline \multirow[t]{2}{*}{$I N D C O N$} & & 0.600 & & 0.185 & & 0.465 \\
\hline & & $\left(1.844^{*}\right)$ & & $(0.898)$ & & $\left(1.837^{*}\right)$ \\
\hline \multirow[t]{2}{*}{ Constant } & -0.702 & -0.509 & -0.226 & -0.147 & -0.213 & -0.167 \\
\hline & $(-2.908 * * *)$ & $(-4.405 * * *)$ & $(-1.601)$ & $(-2.122 * *)$ & $(-1.165)$ & $\left(-1.895^{*}\right)$ \\
\hline R-squared & 0.046 & 0.033 & 0.053 & 0.029 & 0.037 & 0.027 \\
\hline Year fixed effect & Yes & No & Yes & No & No & No \\
\hline Industry fixed effects & Yes & Yes & Yes & No & No & No \\
\hline Robust std error & Yes & Yes & Yes & Yes & Yes & Yes \\
\hline Observations & 2,848 & 5,487 & 2,843 & 5,487 & 2,848 & 5,487 \\
\hline
\end{tabular}


Table 4 - Probit regressions of stock as a payment method choice

The dependent variable is the dummy variable for acquisition paid with stock. NCSKEW is the negative conditional skewness of acquirer-specific stock returns; DUVOL is a down-to-up volatility measure; COUNT is the excess of extreme negative stock returns over extreme positive returns. PRIVATE is a dummy variable representing private targets. LNDEALVALUE is the natural log of the deal value. SIZE is the acquirer's market capitalization measured at the end of fiscal year $t-1$. RELATED is a dummy variable representing deals in the same sector using Fama-French 48 sector classification. COMPETING is a dummy variable contested by two or more bidders. HOSTILE is a dummy variable representing unsolicited deals. $A C Q M K B K, A C Q \mathrm{R} O A$ and $A C Q D E B T$ are the acquirer's industry-adjusted market-to-book ratio, return on asset and total debt-to-asset ratio at the end of the preceding fiscal year. WAVE is the dummy variable equal to 1 for merger wave and 0 otherwise. BULL is the dummy variable equal to 1 for bull market month and 0 otherwise. INDCON is the Herfindahl sales-based acquirer industry concentration in the preceding fiscal year. *,** and $* * *$ indicate the significance levels of $10 \%, 5 \%$ and $1 \%$.

\begin{tabular}{llll}
\hline VARIABLES & Model 1 & Model 2 & Model 3 \\
\hline \% DEALS PAID WITH STOCK & 2.477 & 2.464 & 2.476 \\
& $\left(21.262^{* * *}\right)$ & $\left(21.088^{* * *}\right)$ & \\
NCSKEW & -0.034 & & \\
& $\left(-2.436^{* *}\right)$ & -0.070 & \\
DUVOL & & $\left(-2.722^{* * *}\right)$ & -0.039 \\
COUNT & & & $\left(-2.301^{* *}\right)$ \\
& & & 0.177 \\
PRIVATE & & $\left(4.256^{* * *}\right)$ \\
LNDEALVALUE & 0.176 & 0.177 & 0.140 \\
RELATED & $\left(4.246^{* * *}\right)$ & $\left(4.261^{* * *}\right)$ & $\left(10.509^{* * *}\right)$ \\
COMPETING & 0.140 & 0.141 & 0.404 \\
HOSTILE & $\left(10.524^{* * *}\right)$ & $\left(10.584^{* * *}\right)$ & $\left(4.408^{* * *}\right)$ \\
ACQMKBK & 0.404 & 0.404 & -0.564 \\
ACQROA & $\left(4.412^{* * *}\right)$ & $\left(4.423^{* * *}\right)$ & $\left(-4.623^{* * *}\right)$ \\
& -0.566 & -0.565 & -0.577 \\
& $\left(-4.641^{* * *}\right)$ & $\left(-4.629^{* * *}\right)$ & $\left(-2.615^{* * *}\right)$ \\
& -0.575 & -0.576 & 0.016 \\
& $\left(-2.609^{* * *}\right)$ & $\left(-2.611^{* * *}\right)$ & $\left(4.415^{* * *}\right)$
\end{tabular}




\begin{tabular}{llll} 
ACQDEBT & -1.028 & -1.028 & -1.025 \\
& $\left(-10.696^{* * *}\right)$ & $\left(-10.704^{* * *}\right)$ & $\left(-10.683^{* * *}\right)$ \\
WAVE & 0.089 & 0.090 & $\left(2.178^{* *}\right)$ \\
BULL & $\left(2.177^{* *}\right)$ & $\left(2.200^{* *}\right)$ & -0.053 \\
& -0.055 & -0.055 & $(-1.432)$ \\
INDCON & $(-1.484)$ & $(-1.499)$ & 0.049 \\
& 0.045 & 0.049 & $(0.116)$ \\
Constant & $(0.108)$ & $(0.116)$ & -1.294 \\
& -1.295 & -1.298 & $\left(-12.894^{* * *}\right)$ \\
Pseudo R-squared & $\left(-12.905^{* * *}\right)$ & $\left(-12.945^{* * *}\right)$ & 0.172 \\
Chi- squared & & & $900.4 * * *$ \\
\% correct classification & 0.172 & 0.172 & $70.90 \%$ \\
Industry fixed effects & $894.6^{* * *}$ & $892.1 * * *$ & Yes \\
Robust std err & $70.89 \%$ & $70.91 \%$ & Yes \\
Observations & Yes & Yes & 5,487 \\
\hline
\end{tabular}




\section{Table 5 - Regressions of Change in Acquirer Stock Crash Risk with Self-Selection Bias Corrected}

The dependent variables are the changes in the acquirer's $\triangle N C S K E W$ (in Model 1), $\triangle D U V O L$ (in Model 2) and $\triangle C O U N T$ (in Model 3) from the year before to the year after the acquisitions. NCSKEW is the negative conditional skewness of acquirer-specific stock returns; $D U V O L$ is a down-to-up volatility measure; COUNT is the excess of extreme negative stock returns over extreme positive returns. STOCK is the dummy variable for stock acquirers. PRIVATE is a dummy variable representing private targets. $L N D E A L V A L U E$ is the natural log of the deal value. SIZE is the acquirer's market capitalization measured at the end of fiscal year $t-1$. RELATED is a dummy variable representing deals in the same sector using Fama-French 48 sector classification. COMPETING is a dummy variable contested by two or more bidders. HOSTILE is a dummy variable representing unsolicited deals. $A C Q M K B K, A C Q \mathrm{R} O A$ and $A C Q D E B T$ are the acquirer's industry-adjusted market-to-book ratio, return on asset and total debt-to-asset ratio at the end of the preceding fiscal year. Following Kim, Li and $\mathrm{Li}$ (2014) we also account for the following control variables. STDEV is the standard deviation of firm-specific weekly returns estimated from equation (1) in fiscal year $t-1$. TURNOVER is the average weekly share turnover over the current fiscal year minus that of the previous fiscal year. The weekly share turnover is calculated as the weekly trading volume divided by the total number of shares outstanding during the month of the week. AVGRET is the average of firm-specific weekly returns estimated from equation (1) in fiscal year $t-1$. WAVE is the dummy variable equal to 1 for merger wave and 0 otherwise. $B U L L$ is the dummy variable equal to 1 for bull market month and 0 otherwise. INDCON is the Herfindahl sales-based acquirer industry concentration in the preceding fiscal year. MILLS NCSKEW, MILLS DUVOL and MILLS COUNT are the inverse Mills ratio obtained from Model 1,2 and 3, respectively, in Table $4 . *{ }^{* *}$ and $* * *$ indicate the significance levels of $10 \%, 5 \%$ and $1 \%$.

\begin{tabular}{llll}
\hline Variables & Model 1 - ANCSKEW & Model 2 - SDUVOL & Model 3 - COUNT \\
\hline STOCK & 0.039 & 0.047 & 0.066 \\
PRIVATE & $\left(2.408^{* *}\right)$ & $\left(2.088^{* *}\right)$ & $\left(1.985^{* *}\right)$ \\
& 0.006 & 0.021 & -0.008 \\
LNDEALVALUE & $(0.142)$ & $(0.897)$ & $(-0.234)$ \\
& -0.008 & 0.002 & 0.006 \\
SIZE & $(-0.511)$ & $(0.205)$ & $(0.521)$ \\
& 0.004 & -0.016 & -0.004 \\
RELATED & $(0.428)$ & $\left(-2.531^{* *}\right)$ & $(-0.548)$ \\
& -0.137 & -0.068 & -0.132 \\
COMPETING & $\left(-1.897^{*}\right)$ & $(-1.571)$ & $\left(-2.305^{* *}\right)$ \\
HOSTILE & 0.118 & 0.074 & 0.057 \\
ACQMKBK & $(1.091)$ & $(1.105)$ & $(0.677)$ \\
ACQROA & -0.164 & -0.135 & -0.055 \\
ACQDEBT & $(-0.934)$ & $(-1.178)$ & $(-0.342)$ \\
& 0.001 & 0.001 & 0.001 \\
& $\left(1.646^{*}\right)$ & $\left(2.297^{* *}\right)$ & $(1.291)$ \\
& 0.031 & -0.059 & -0.082 \\
& $(0.235)$ & $(-0.761)$ & $(-0.953)$
\end{tabular}




\begin{tabular}{|c|c|c|c|}
\hline & $(2.167 * *)$ & $(2.298 * *)$ & $(-0.678)$ \\
\hline \multirow[t]{2}{*}{$S T D E V \times 100$} & 0.259 & 0.072 & 0.078 \\
\hline & $(2.766 * * *)$ & $(1.270)$ & $(1.125)$ \\
\hline \multirow[t]{2}{*}{$T U R N O V E R \times 100$} & 0.053 & 0.028 & 0.033 \\
\hline & $\left(3.676^{* * *}\right)$ & $(3.249 * * *)$ & $(4.042 * * *)$ \\
\hline \multirow[t]{2}{*}{$A V G R E T \times 100$} & 13.403 & 4.950 & 5.474 \\
\hline & $(2.860 * * *)$ & $\left(1.681^{*}\right)$ & $\left(1.850^{*}\right)$ \\
\hline \multirow[t]{2}{*}{ WAVE } & 0.135 & 0.056 & 0.077 \\
\hline & $(2.845 * * *)$ & $(1.983 * *)$ & $(2.297 * *)$ \\
\hline \multirow[t]{2}{*}{$B U L L$} & -0.003 & 0.017 & -0.022 \\
\hline & $(-0.081)$ & $(0.854)$ & $(-0.860)$ \\
\hline \multirow[t]{2}{*}{$I N D C O N$} & 0.580 & 0.231 & 0.469 \\
\hline & (1.603) & $(1.025)$ & $(1.904 *)$ \\
\hline \multirow[t]{2}{*}{ MILLS_NCSKEW } & -0.038 & & \\
\hline & $(-0.399)$ & & \\
\hline \multirow[t]{2}{*}{ MILLS_DUVOL } & & -0.007 & \\
\hline & & $(-0.124)$ & \\
\hline \multirow[t]{2}{*}{ MILLS_COUNT } & & & -0.026 \\
\hline & & & $(-0.469)$ \\
\hline \multirow[t]{2}{*}{ Constant } & -0.262 & -0.133 & -0.078 \\
\hline & $(-1.453)$ & $(-1.179)$ & $(-0.612)$ \\
\hline Adj. R-squared & 0.027 & 0.038 & 0.022 \\
\hline Robust std err & Yes & Yes & Yes \\
\hline Observations & 5,092 & 5,082 & 5,092 \\
\hline
\end{tabular}


Table 6 - Regressions of Change in Acquirer Stock Crash Risk on Percent of Stock Payment

The dependent variables are the changes in the acquirer's $\triangle N C S K E W$ (in Model 1), $\triangle D U V O L$ (in Model 2) and $\triangle C O U N T$ (in Model 3) from the year before to the year after the acquisitions. NCSKEW is the negative conditional skewness of acquirer-specific stock returns; $D U V O L$ is a down-to-up volatility measure; COUNT is the excess of extreme negative stock returns over extreme positive returns. PCTSTOCK is the percentage of the deal value being paid with the acquirer stock. PRIVATE is a dummy variable representing private targets. LNDEALVALUE is the natural log of the deal value. SIZE is the acquirer's market capitalization measured at the end of fiscal year $t-1$. RELATED is a dummy variable representing deals in the same sector using Fama-French 48 sector classification. COMPETING is a dummy variable contested by two or more bidders. HOSTILE is a dummy variable representing unsolicited deals.

$A C Q M K B K, A C Q \mathrm{R} O A$ and $A C Q D E B T$ are the acquirer's industry-adjusted market-to-book ratio, return on asset and total debt-to-asset ratio at the end of the preceding fiscal year. Following Kim, $\mathrm{Li}$ and $\mathrm{Li}(2014)$ we also account for the following control variables. STDEV is the standard deviation of firm-specific weekly returns estimated from equation (1) in fiscal year $t-1$. TURNOVER is the average weekly share turnover over the current fiscal year minus that of the previous fiscal year. The weekly share turnover is calculated as the weekly trading volume divided by the total number of shares outstanding during the month of the week. AVGRET is the average of firm-specific weekly returns estimated from equation (1) in fiscal year $t-1$. WAVE is the dummy variable equal to 1 for merger wave and 0 otherwise. BULL is the dummy variable equal to 1 for bull market month and 0 otherwise. INDCON is the Herfindahl sales-based acquirer industry concentration in the preceding fiscal year. MILLS NCSKEW, MILLS DUVOL and MILLS COUNT are the inverse Mills ratio obtained from Model 1,2 and 3, respectively, in Table $4 . *, * *$ and *** indicate the significance levels of $10 \%, 5 \%$ and $1 \%$.

\begin{tabular}{|c|c|c|c|}
\hline Variables & Model 1-ANCSKEW & Model 2-ADUVOL & Model 3-ACOUNT \\
\hline \multirow[t]{2}{*}{ PCTSTOCK } & 0.066 & 0.051 & 0.055 \\
\hline & $\left(2.385^{* *}\right)$ & $\left(2.035^{* *}\right)$ & $\left(2.156^{* *}\right)$ \\
\hline \multirow[t]{2}{*}{ PRIVATE } & 0.021 & 0.037 & -0.004 \\
\hline & $(1.570)$ & $(1.700 *)$ & $(-0.210)$ \\
\hline \multirow[t]{2}{*}{ LNDEALVALUE } & -0.004 & 0.009 & 0.007 \\
\hline & $(-0.280)$ & (1.194) & $(0.726)$ \\
\hline \multirow[t]{2}{*}{ SIZE } & 0.007 & -0.012 & -0.004 \\
\hline & $(0.733)$ & $(-2.131 * *)$ & $(-0.512)$ \\
\hline \multirow[t]{2}{*}{ RELATED } & -0.121 & -0.061 & -0.138 \\
\hline & $\left(-1.738^{*}\right)$ & $(-1.446)$ & $(-2.249 * *)$ \\
\hline \multirow[t]{2}{*}{ COMPETING } & 0.107 & 0.062 & 0.049 \\
\hline & $(1.026)$ & $(0.954)$ & $(0.711)$ \\
\hline \multirow[t]{2}{*}{ HOSTILE } & -0.186 & -0.172 & -0.076 \\
\hline & $(-1.064)$ & $(-1.487)$ & $(-0.462)$ \\
\hline \multirow[t]{2}{*}{$A C Q M K B K$} & 0.001 & 0.001 & 0.001 \\
\hline & $(1.744 *)$ & $(2.543 * *)$ & $(1.282)$ \\
\hline \multirow[t]{2}{*}{$A C Q R O A$} & -0.002 & -0.100 & -0.101 \\
\hline & $(-0.019)$ & $(-1.437)$ & $(-1.351)$ \\
\hline \multirow[t]{2}{*}{$A C Q D E B T$} & 0.148 & 0.084 & -0.061 \\
\hline & $(1.971 * *)$ & $(1.820 *)$ & $(-1.092)$ \\
\hline \multirow[t]{2}{*}{$S T D E V \times 100$} & 0.256 & 0.068 & 0.087 \\
\hline & $(3.103 * * *)$ & (1.387) & $(1.432)$ \\
\hline
\end{tabular}




\begin{tabular}{llll} 
TURNOVER $\times 100$ & 0.051 & 0.025 & 0.035 \\
& $\left(3.714^{* * *}\right)$ & $\left(3.130^{* * *}\right)$ & $\left(4.127^{* * *}\right)$ \\
AVGRET $\times 100$ & 12.628 & 3.718 & $\left(1.947^{*}\right)$ \\
WAVE & $\left(2.893^{* * *}\right)$ & $(1.435)$ & 0.042 \\
& 0.077 & 0.044 & $(1.628)$ \\
BULL & $\left(2.114^{* *}\right)$ & $\left(2.021^{* *}\right)$ & -0.019 \\
& 0.002 & 0.019 & $(-0.751)$ \\
INDCON & $(0.053)$ & $(0.993)$ & 0.420 \\
& 0.475 & 0.126 & $(1.567)$ \\
MILLS_NCSKEW & $(1.353)$ & $(0.576)$ & \\
MILLS_DUVOL & -0.002 & & 0.000 \\
MILLS_COUNT & $(-0.031)$ & 0.032 & $(0.005)$ \\
Constant & & $(0.958)$ & -0.036 \\
& & & $(-0.321)$ \\
Adj. R-squared & & -0.078 & 0.018 \\
Year fixed effect & -0.281 & $(-0.931)$ & Yes \\
Industry fixed effects & $\left(-2.009^{* *}\right)$ & & Yes \\
Robust std err & & 0.021 & Yes \\
Observations & 0.02 & Yes & Yes \\
\hline
\end{tabular}


Table 7 - Regressions of Change in Acquirer Stock Crash Risk - By Subsamples

We split the sample into subsamples based upon the acquirer characteristics in the year preceding the acquisition. The dependent variables are the changes in the acquirer's $\triangle N C S K E W$ (in Model 1), $\triangle D U V O L$ (in Model 2) and $\triangle C O U N T$ (in Model 3) from the year before to the year after the acquisitions. $N C S K E W$ is the negative conditional skewness of acquirer-specific stock returns; $D U V O L$ is a down-to-up volatility measure; COUNT is the excess of extreme negative stock returns over extreme positive returns. STOCK is the dummy variable for stock acquirers. Other control variables are included but are not reported for brevity. $* * *$ and $* * *$ indicate the significance levels of $10 \%, 5 \%$ and $1 \%$.

\section{Panel A - Low Valuation vs. High Valuation}

\begin{tabular}{lllllll} 
& \multicolumn{2}{c}{ Model 1- - NCSKEW } & \multicolumn{2}{c}{ Model 2- $\triangle D U V O L$} & \multicolumn{2}{c}{ Model 3 $-\triangle C O U N T$} \\
Variables & Low valuation & High valuation & Low valuation & High valuation & Low valuation & High valuation \\
\hline STOCK & 0.021 & 0.088 & 0.010 & 0.063 & 0.019 & 0.042 \\
& $(0.412)$ & $\left(2.576^{* * *}\right)$ & $(0.307)$ & $\left(1.979^{* *}\right)$ & $(0.472)$ & $\left(2.102^{* *}\right)$ \\
Adj. R-squared & 0.024 & 0.021 & 0.024 & 0.03 & 0.016 & 0.026 \\
Observations & 2,473 & 2,619 & 2,464 & 2,618 & 2,473 & 2,619 \\
\hline
\end{tabular}

Panel B - Private vs Public Targets

\begin{tabular}{lllllll} 
& Model 1 $1-\triangle N C S K E W$ & \multicolumn{2}{c}{ Model 2- } & \multicolumn{2}{c}{ MUVOL } & \multicolumn{2}{c}{ Model $3-\triangle C O U N T$} \\
Variables & Public targets & Private targets & Public targets & Private targets & Public targets & Private targets \\
\hline STOCK & 0.122 & -0.001 & 0.057 & 0.026 & 0.085 & -0.012 \\
& $\left(2.643^{* * *}\right)$ & $(-0.017)$ & $\left(2.042^{* *}\right)$ & $(0.705)$ & $\left(2.328^{* *}\right)$ & $(-0.307)$ \\
Adj. R-squared & 0.027 & 0.025 & 0.023 & 0.026 & 0.022 & 0.021 \\
Observations & 2,817 & 2,275 & 2,812 & 2,270 & 2,817 & 2,275 \\
\hline
\end{tabular}

\begin{tabular}{|c|c|c|c|c|c|c|}
\hline \multirow{2}{*}{\multicolumn{7}{|c|}{ Panel C-Less Profitable vs. More Profitable }} \\
\hline & & & & & & \\
\hline & \multicolumn{2}{|c|}{ Model $1-\triangle N C S K E W$} & \multicolumn{2}{|c|}{ Model $2-\triangle D U V O L$} & \multicolumn{2}{|c|}{ Model $3-\triangle C O U N T$} \\
\hline & Less profitable & More profitable & Less profitable & More profitable & Less profitable & More profitable \\
\hline STOCK & 0.086 & 0.053 & 0.049 & 0.044 & 0.055 & 0.032 \\
\hline & $\left(2.638^{* * *}\right)$ & $(0.999)$ & $(2.545 * *)$ & $(1.361)$ & $(2.460 * *)$ & $(0.925)$ \\
\hline Adj. R-squared & 0.029 & 0.018 & 0.028 & 0.018 & 0.022 & 0.016 \\
\hline Observations & 2,483 & 2,609 & 2,475 & 2,607 & 2,483 & 2,609 \\
\hline \multicolumn{7}{|c|}{ Panel D-Low Leverage vs. High Leverage } \\
\hline & \multicolumn{2}{|c|}{ Model $1-\triangle N C S K E W$} & \multicolumn{2}{|c|}{ Model $2-\triangle D U V O L$} & \multicolumn{2}{|c|}{ Model 3 - $\triangle C O U N T$} \\
\hline & Low Leverage & High Leverage & Low Leverage & High Leverage & Low Leverage & High Leverage \\
\hline STOCK & 0.051 & 0.068 & 0.014 & 0.041 & 0.025 & 0.050 \\
\hline & $(0.878)$ & $(2.404 * *)$ & $(0.478)$ & $(2.069 * *)$ & $(0.610)$ & $(2.341 * *)$ \\
\hline Adj. R-squared & 0.03 & 0.02 & 0.024 & 0.023 & 0.017 & 0.020 \\
\hline Observations & 2,549 & 2,543 & 2,542 & 2,540 & 2,549 & 2,543 \\
\hline \multicolumn{7}{|c|}{ Panel E-Crisis vs. Non-Crisis Period } \\
\hline & \multicolumn{2}{|c|}{ Model $1-\triangle N C S K E W$} & \multicolumn{2}{|c|}{ Model $2-\triangle D U V O L$} & \multicolumn{2}{|c|}{ Model 3 - $\triangle$ COUNT } \\
\hline & Non-Crisis & Crisis & Non-Crisis & Crisis & Non-Crisis & Crisis \\
\hline
\end{tabular}




\begin{tabular}{lllllll}
\hline STOCK & 0.081 & -0.063 & 0.056 & 0.027 & 0.069 & -0.006 \\
& $\left(2.086^{* *}\right)$ & $(-0.455)$ & $\left(2.161^{* *}\right)$ & $(0.586)$ & $\left(2.159^{* *}\right)$ & $(-0.120)$ \\
Adj. R-squared & 0.022 & 0.035 & 0.019 & 0.04 & 0.017 & 0.037 \\
Observations & 4,548 & 544 & 4,539 & 543 & 4,548 & 544 \\
\hline
\end{tabular}


Table 8 - Regressions of Change in Acquirer Stock Crash Risk - Differential from Non-Acquiring Firms in the Same Industry and Same Valuation Terciles

The dependent variables are the differentials between the changes in the acquirer's crash risk ( $\triangle N C S K E W, \triangle D U V O L$ and $\triangle C O U N T$ ) from the year before to the year after the acquisitions, and the mean (Panel A) or median (Panel B) of crash risk changes of all non-acquiring firms in the same industry and same tercile of market-to-book ratio in the previous year. NCSKEW is the negative conditional skewness of acquirer-specific stock returns; $D U V O L$ is a down-to-up volatility measure; COUNT is the excess of extreme negative stock returns over extreme positive returns. STOCK is the dummy variable for stock acquirers. PRIVATE is a dummy variable representing private targets. LNDEALVALUE is the natural log of the deal value. SIZE is the acquirer's market capitalization measured at the end of fiscal year $t-1$. RELATED is a dummy variable representing deals in the same sector using Fama-French 48 sector classification. COMPETING is a dummy variable contested by two or more bidders. HOSTILE is a dummy variable representing unsolicited deals. $A C Q M K B K, A C Q \mathrm{R} O A$ and $A C Q D E B T$ are the acquirer's industry-adjusted market-to-book ratio, return on asset and total debt-to-asset ratio at the end of the preceding fiscal year. Following Kim, $\mathrm{Li}$ and $\mathrm{Li}$ (2014) we also account for the following control variables. STDEV is the standard deviation of firm-specific weekly returns estimated from equation (1) in fiscal year $t-1$. TURNOVER is the average weekly share turnover over the current fiscal year minus that of the previous fiscal year. The weekly share turnover is calculated as the weekly trading volume divided by the total number of shares outstanding during the month of the week. $A V G R E T$ is the average of firm-specific weekly returns estimated from equation (1) in fiscal year $t-1$. WAVE is the dummy variable equal to 1 for merger wave and 0 otherwise. $B U L L$ is the dummy variable equal to 1 for bull market month and 0 otherwise. INDCON is the Herfindahl sales-based acquirer industry concentration in the preceding fiscal year. MILLS_NCSKEW, MILLS_DUVOL and MILLS_COUNT are the inverse Mills ratio obtained from Model 1, 2 and 3 , respectively, in Table $4 . *, * *$ and $* * *$ indicate the significance levels of $10 \%, 5 \%$ and $1 \%$.

\begin{tabular}{|c|c|c|c|c|c|c|}
\hline & \multicolumn{3}{|c|}{ Panel A - Mean Adjusted } & \multicolumn{3}{|c|}{ Panel B - Median Adjusted } \\
\hline & $\triangle N C S K E W$ & $\triangle D U V O L$ & $\triangle C O U N T$ & $\triangle N C S K E W$ & $\triangle D U V O L$ & $\triangle C O U N T$ \\
\hline \multirow[t]{2}{*}{ STOCK } & 0.070 & 0.045 & 0.078 & 0.071 & 0.045 & 0.077 \\
\hline & $\left(2.346^{* *}\right)$ & $\left(1.996^{* *}\right)$ & $(2.467 * *)$ & $(2.372 * *)$ & $\left(1.996^{* *}\right)$ & $(2.487 * *)$ \\
\hline \multirow[t]{2}{*}{ PRIVATE } & 0.016 & 0.035 & -0.012 & 0.014 & 0.035 & -0.007 \\
\hline & $(0.447)$ & $(1.607)$ & $(-0.2905)$ & $(0.401)$ & $(1.637)$ & $(-0.176)$ \\
\hline \multirow[t]{2}{*}{ LNDEALVALUE } & -0.004 & 0.007 & 0.009 & -0.004 & 0.007 & 0.005 \\
\hline & $(-0.320)$ & $(0.957)$ & $(1.24)$ & $(-0.296)$ & $(0.947)$ & $(0.701)$ \\
\hline \multirow[t]{2}{*}{ SIZE } & 0.006 & -0.011 & -0.006 & 0.005 & -0.011 & -0.003 \\
\hline & $(0.602)$ & $\left(-1.776^{*}\right)$ & $(-0.816)$ & $(0.505)$ & $\left(-1.931^{*}\right)$ & $(-0.375)$ \\
\hline \multirow[t]{2}{*}{ RELATED } & -0.120 & -0.061 & -0.163 & -0.125 & -0.063 & -0.172 \\
\hline & $(-1.702 *)$ & $(-1.397)$ & $(-2.279 * *)$ & $\left(-1.786^{*}\right)$ & $(-1.442)$ & $(-2.221 * *)$ \\
\hline \multirow[t]{2}{*}{ COMPETING } & 0.100 & 0.058 & 0.053 & 0.105 & 0.060 & 0.055 \\
\hline & $(0.963)$ & $(0.869)$ & $(0.839)$ & (1.009) & $(0.913)$ & $(0.719)$ \\
\hline \multirow[t]{2}{*}{ HOSTILE } & -0.175 & -0.166 & -0.069 & -0.171 & -0.162 & -0.069 \\
\hline & $(-0.976)$ & $(-1.375)$ & $(-0.436)$ & $(-0.953)$ & $(-1.333)$ & $(-0.420)$ \\
\hline \multirow[t]{2}{*}{$A C Q M K B K$} & 0.001 & 0.001 & 0.001 & 0.001 & 0.001 & 0.001 \\
\hline & $(1.621)$ & $(2.378 * *)$ & $(1.160)$ & (1.597) & $(2.350 * *)$ & (1.082) \\
\hline
\end{tabular}




\begin{tabular}{|c|c|c|c|c|c|c|}
\hline$A C Q R O A$ & $\begin{array}{l}0.008 \\
(0.064)\end{array}$ & $\begin{array}{l}-0.098 \\
(-1.332)\end{array}$ & $\begin{array}{l}-0.128 \\
(-1.219)\end{array}$ & $\begin{array}{l}0.020 \\
(0.165)\end{array}$ & $\begin{array}{l}-0.088 \\
(-1.194)\end{array}$ & $\begin{array}{l}-0.141 \\
(-1.275)\end{array}$ \\
\hline$A C Q D E B T$ & $\begin{array}{l}0.169 \\
\left(2.232^{* *}\right)\end{array}$ & $\begin{array}{l}0.080 \\
\left(1.706^{*}\right)\end{array}$ & $\begin{array}{l}-0.031 \\
(-0.891)\end{array}$ & $\begin{array}{l}0.181 \\
\left(2.397^{* *}\right)\end{array}$ & $\begin{array}{l}0.085 \\
\left(1.810^{*}\right)\end{array}$ & $\begin{array}{l}-0.075 \\
(-1.236)\end{array}$ \\
\hline$S T D E V \times 100$ & $\begin{array}{l}0.241 \\
(2.737 * * *)\end{array}$ & $\begin{array}{l}0.070 \\
(1.330)\end{array}$ & $\begin{array}{l}0.103 \\
(1.099)\end{array}$ & $\begin{array}{l}0.236 \\
(2.680 * * *)\end{array}$ & $\begin{array}{l}0.066 \\
(1.256)\end{array}$ & $\begin{array}{l}0.121 \\
(0.832)\end{array}$ \\
\hline TURNOVER $\times 100$ & $\begin{array}{l}0.051 \\
(2.999 * * *)\end{array}$ & $\begin{array}{l}0.025 \\
(2.640 * * *)\end{array}$ & $\begin{array}{l}0.039 \\
(4.105 * * *)\end{array}$ & $\begin{array}{l}0.050 \\
(2.969 * * *)\end{array}$ & $\begin{array}{l}0.025 \\
(2.625 * * *)\end{array}$ & $\begin{array}{l}0.039 \\
(3.608 * * *)\end{array}$ \\
\hline$A V G R E T \times 100$ & $\begin{array}{l}11.987 \\
\left(2.656^{* * *}\right)\end{array}$ & $\begin{array}{l}3.653 \\
(1.328)\end{array}$ & $\begin{array}{l}6.976 \\
(2.048 * *)\end{array}$ & $\begin{array}{l}11.833 \\
(2.624 * * *)\end{array}$ & $\begin{array}{l}3.479 \\
(1.272)\end{array}$ & $\begin{array}{l}5.724 \\
(1.663)\end{array}$ \\
\hline WAVE & $\begin{array}{l}0.078 \\
(2.067 * *)\end{array}$ & $\begin{array}{l}0.044 \\
\left(1.991^{* *}\right)\end{array}$ & $\begin{array}{l}0.044 \\
(1.251)\end{array}$ & $\begin{array}{l}0.073 \\
(1.921 *)\end{array}$ & $\begin{array}{l}0.046 \\
\left(2.046^{* *}\right)\end{array}$ & $\begin{array}{l}0.043 \\
(1.501)\end{array}$ \\
\hline$B U L L$ & $\begin{array}{l}0.005 \\
(0.150)\end{array}$ & $\begin{array}{l}0.022 \\
(1.148)\end{array}$ & $\begin{array}{l}-0.031 \\
(-1.191)\end{array}$ & $\begin{array}{l}0.004 \\
(0.118)\end{array}$ & $\begin{array}{l}0.021 \\
(1.113)\end{array}$ & $\begin{array}{l}-0.019 \\
(-1.122)\end{array}$ \\
\hline INDCON & $\begin{array}{l}0.661 \\
(2.044 * *)\end{array}$ & $\begin{array}{l}0.242 \\
(1.254)\end{array}$ & $\begin{array}{l}0.483 \\
\left(2.16^{* *}\right)\end{array}$ & $\begin{array}{l}0.613 \\
\left(1.895^{*}\right)\end{array}$ & $\begin{array}{l}0.275 \\
(1.428)\end{array}$ & $\begin{array}{l}0.527 \\
\left(1.865^{*}\right)\end{array}$ \\
\hline MILLS_NCSKEW & $\begin{array}{l}0.023 \\
(0.409)\end{array}$ & & & $\begin{array}{l}0.008 \\
(0.142)\end{array}$ & & \\
\hline MILLS_DUVOL & & $\begin{array}{l}0.040 \\
(1.207)\end{array}$ & & & $\begin{array}{l}0.036 \\
(1.098)\end{array}$ & \\
\hline MILLS_COUNT & & & $\begin{array}{l}0.021 \\
(0.515)\end{array}$ & & & $\begin{array}{l}0.006 \\
(0.094)\end{array}$ \\
\hline Constant & $\begin{array}{l}-0.403 \\
(-2.742 * * *)\end{array}$ & $\begin{array}{l}-0.160 \\
\left(-1.817^{*}\right)\end{array}$ & $\begin{array}{l}-0.085 \\
(-0.859)\end{array}$ & $\begin{array}{l}-0.381 \\
\left(-2.594^{* * *}\right)\end{array}$ & $\begin{array}{l}-0.156 \\
\left(-1.776^{*}\right)\end{array}$ & $\begin{array}{l}-0.052 \\
(-0.473)\end{array}$ \\
\hline Adjusted R-squared & 0.02 & 0.021 & 0.018 & 0.02 & 0.021 & 0.018 \\
\hline Year fixed effect & Yes & Yes & Yes & Yes & Yes & Yes \\
\hline Industry fixed effects & Yes & Yes & Yes & Yes & Yes & Yes \\
\hline Industry fixed effects & Yes & Yes & Yes & Yes & Yes & Yes \\
\hline Observations & 4,869 & 4,863 & 4,869 & 4,869 & 4,863 & 4,869 \\
\hline
\end{tabular}




\section{Table 9 - A Two-Stage Regression of Acquirer's Crash Risk Change}

The dependent variables in Panel A (Stage 1) are the changes in the acquirer's $\triangle N C S K E W, \triangle D U V O L$ and $\triangle C O U N T$ from the year before to the year after the acquisitions. $N C S K E W$ is the negative conditional skewness of acquirer-specific stock returns; $D U V O L$ is a down-to-up volatility measure; COUNT is the excess of extreme negative stock returns over extreme positive returns. SIZECHG is the percentage change in acquirer's market capitalization between the fiscal years $t-1$ and t. $M K B K C H G$ is the percentage change in acquirer's industry-adjusted market-to-book ratio. $R O A C H G$ is the percentage change in acquirer's industry-adjusted return on assets. $D E B T C H G$ is the percentage change in acquirer's industry-adjusted total debt-to-asset ratio. Following Kim, Li and $\mathrm{Li}(2014)$ we also account for the following control variables. $S T D E V \times 100 C H G$ is the percentage change in standard deviation of firm-specific weekly returns estimated from equation (1) between the fiscal years $t-1$ and t. TURNOVER $\times 100 C H G$ is the percentage change in TURNOVER. TURNOVER is the average weekly share turnover over the current fiscal year minus that of the previous fiscal year. The weekly share turnover is calculated as the weekly trading volume divided by the total number of shares outstanding during the month of the week. AVGRET $\times 100 C H G$ is the percentage change in average of firmspecific weekly returns estimated from equation (1). The dependent variables in Panel B (Stage 2) are the residuals from Panel A. STOCK is the dummy variable for stock acquirers. PRIVATE is a dummy variable representing private targets. LNDEALVALUE is the natural log of the deal value. RELATED is a dummy variable representing deals in the same sector using Fama-French 48 sector classification. COMPETING is a dummy variable contested by two or more bidders. HOSTILE is a dummy variable representing unsolicited deals. WAVE is the dummy variable equal to 1 for merger wave and 0 otherwise. BULL is the dummy variable equal to 1 for bull market month and 0 otherwise. INDCON is the Herfindahl sales-based acquirer industry concentration in the preceding fiscal year. MILLS_NCSKEW, MILLS_DUVOL and MILLS_COUNT are the inverse Mills ratio obtained from Model 1, 2 and 3, respectively, in Table 4. *, ** and *** indicate the significance levels of $10 \%, 5 \%$ and $1 \%$.

\begin{tabular}{|c|c|c|c|c|c|c|c|}
\hline Panel $A$-Stage 1 & & & & Panel B-Stage 2 & & & \\
\hline Variables & $\triangle N C S K E W$ & $\triangle D U V O L$ & $\triangle C O U N T$ & Variables & $\triangle N C S K E W$ & $\triangle D U V O L$ & $\triangle C O U N T$ \\
\hline SIZECHG & $\begin{array}{l}-0.094 \\
(-3.152 * * *)\end{array}$ & $\begin{array}{l}-0.046 \\
(-2.884 * * *)\end{array}$ & $\begin{array}{l}-0.063 \\
(-3.570 * * *)\end{array}$ & STOCK & $\begin{array}{l}0.114 \\
\left(2.520^{* *}\right)\end{array}$ & $\begin{array}{l}0.048 \\
(1.911 *)\end{array}$ & $\begin{array}{l}0.082 \\
\left(2.351^{* *}\right)\end{array}$ \\
\hline$M K B K C H G$ & $\begin{array}{l}0.000 \\
\left(2.443^{* *}\right)\end{array}$ & $\begin{array}{l}0.000 \\
(2.857 * * *)\end{array}$ & $\begin{array}{l}0.001 \\
(1.218)\end{array}$ & PRIVATE & $\begin{array}{l}0.099 \\
\left(2.018^{* *}\right)\end{array}$ & $\begin{array}{l}0.039 \\
(1.426)\end{array}$ & $\begin{array}{l}0.076 \\
(1.465)\end{array}$ \\
\hline ROACHG & $\begin{array}{l}0.055 \\
(1.384)\end{array}$ & $\begin{array}{l}0.026 \\
(0.897)\end{array}$ & $\begin{array}{l}0.020 \\
(1.309)\end{array}$ & LNDEALVALUE & $\begin{array}{l}0.006 \\
(0.590)\end{array}$ & $\begin{array}{l}-0.001 \\
(-0.190)\end{array}$ & $\begin{array}{l}0.009 \\
(0.910)\end{array}$ \\
\hline DEBTCHG & $\begin{array}{l}0.010 \\
(0.101)\end{array}$ & $\begin{array}{l}0.013 \\
(0.182)\end{array}$ & $\begin{array}{l}0.037 \\
(0.626)\end{array}$ & RELATED & $\begin{array}{l}-0.125 \\
(-1.779 *)\end{array}$ & $\begin{array}{l}-0.058 \\
(-1.355)\end{array}$ & $\begin{array}{l}-0.166 \\
\left(-2.234^{* *}\right)\end{array}$ \\
\hline$S T D E V \times 100 C H G$ & $\begin{array}{l}0.269 \\
(3.024 * * *)\end{array}$ & $\begin{array}{l}0.178 \\
(3.328 * * *)\end{array}$ & $\begin{array}{l}0.130 \\
\left(1.943^{*}\right)\end{array}$ & COMPETING & $\begin{array}{l}0.076 \\
(0.724)\end{array}$ & $\begin{array}{l}0.042 \\
(0.650)\end{array}$ & $\begin{array}{l}0.050 \\
(0.620)\end{array}$ \\
\hline TURNOVER $\times 100 C H G$ & $\begin{array}{l}0.064 \\
(2.707 * * *)\end{array}$ & $\begin{array}{l}0.031 \\
\left(2.616^{* * *}\right)\end{array}$ & $\begin{array}{l}0.037 \\
(3.829 * * *)\end{array}$ & HOSTILE & $\begin{array}{l}-0.168 \\
(-0.968)\end{array}$ & $\begin{array}{l}-0.105 \\
(-0.932)\end{array}$ & $\begin{array}{l}-0.060 \\
(-0.307)\end{array}$ \\
\hline$A V G R E T \times 100 C H G$ & $\begin{array}{l}15.429 \\
\left(3.040^{* * *}\right)\end{array}$ & $\begin{array}{l}9.881 \\
(3.156 * * *)\end{array}$ & $\begin{array}{l}8.181 \\
(2.203 * *)\end{array}$ & WAVE & $\begin{array}{l}0.081 \\
(2.171 * *)\end{array}$ & $\begin{array}{l}0.032 \\
(1.487)\end{array}$ & $\begin{array}{l}0.041 \\
(1.302)\end{array}$ \\
\hline Constant & $\begin{array}{l}-0.272 \\
\left(-1.815^{*}\right)\end{array}$ & $\begin{array}{l}-0.096 \\
(-1.012)\end{array}$ & $\begin{array}{l}-0.192 \\
(-1.722 *)\end{array}$ & $B U L L$ & $\begin{array}{l}-0.008 \\
(-0.259)\end{array}$ & $\begin{array}{l}0.016 \\
(0.856)\end{array}$ & $\begin{array}{l}-0.020 \\
(-0.854)\end{array}$ \\
\hline Adj. R-squared & 0.022 & 0.033 & 0.015 & $I N D C O N$ & $\begin{array}{l}0.610 \\
(1.914 *)\end{array}$ & $\begin{array}{l}0.256 \\
(1.365)\end{array}$ & $\begin{array}{l}0.462 \\
(2.015 * *)\end{array}$ \\
\hline Year fixed effect & Yes & Yes & Yes & MILLS_NCSKEW & 0.057 & & \\
\hline Industry fixed effects & Yes & Yes & Yes & & (1.136) & & \\
\hline Robust std err & Yes & Yes & Yes & MILLS_DUVOL & & 0.033 & \\
\hline
\end{tabular}




\begin{tabular}{|c|c|c|c|c|c|c|}
\hline \multirow[t]{8}{*}{ Observations } & \multirow[t]{8}{*}{4,609} & \multirow[t]{8}{*}{4,604} & \multirow{2}{*}{\multicolumn{3}{|c|}{ MILLS_COUNT }} & \\
\hline & & & & & & 0.004 \\
\hline & & & Constant & $\begin{array}{l}-0.206 \\
(-2.230 * *)\end{array}$ & $\begin{array}{l}-0.091 \\
(-1.688 *)\end{array}$ & $\begin{array}{l}-0.104 \\
(-1.409)\end{array}$ \\
\hline & & & Adj. R-squared & 0.023 & 0.021 & 0.024 \\
\hline & & & Year fixed effect & No & No & No \\
\hline & & & $\begin{array}{l}\text { Industry fixed } \\
\text { effects }\end{array}$ & No & No & No \\
\hline & & & Robust std err. & Yes & Yes & Yes \\
\hline & & & Observations & 4,608 & 4,603 & 4,608 \\
\hline
\end{tabular}


